\title{
De etnomusicología española: notas de historia. Una aproximación al folklore musical del XVIII a través de la literatura
}

\author{
José Antonio Gómez Rodríguez \\ Universidad de Oviedo
}

Pese a la importancia —e influencia - que la música ha tenido en la historia, es raro que los que la cuentan se acuerden de ella; y más de la que nos ocupa - la popular-, que ni gozó de los privilegios de la estampa — que tanta música mala nos ha legado- ni del aplauso de los poderosos, que entregaron a las «áreas» y «recigados» de los capones. De la música que se hacía en las aldeas, como la que corría por la Corte o inundaba las principales villas, apenas sabemos nada porque nadie habló de ella en su momento. Cabe pensar, no obstante, que unas y otras debieron tener su importancia porque una tradición que llega hasta hoy recuerda todavía unos cuantos temas que hunden sus raíces en el cancionero musical de la lírica popular dieciochesca, y no parecen pocos los bailes y danzas tradicionales de nuestros días que son un ejemplo de cultura degradada — gesunkenes Kulturgut - del período.

\section{De músicas cultas y populares}

Una de las constantes de la musicología europea del siglo pasado - todavía hoy de la española - ha sido su empeño por trazar una clara división entre músicas populares y cultas. Como ha puesto de manifiesto Josep Martí, pocas veces se ha tenido en cuenta que dicha dicotomía es «difusa», 
«culturalmente subjetiva», y que sus términos — popular/culto— «no se encuentran tan sólo en relación de oposición sino también de complementariedad $^{1}{ }$.

Es fundamental, pues, relativizar su importancia y, sobre todo, no extremar la contraposición de sus significados, pues en el fondo constituyen un continuum y en ocasiones son una misma cosa: «En las culturas folklóricas de Europa y América es más difícil separar la música folklórica de la música elaborada, cultivada o artística, o de la música popular. La distinción es gradual y poco clara. La vida musical de las ciudades y de las cortes, dirigida por músicos preparados profesionalmente con la utilización de la música escrita, es indudablemente diferente de la de las aldeas, en las que la música se transmite por tradición oral y en las que la mayor parte de la gente participa activamente sin tener gran especialización musical. Pero también existe música folklórica en las ciudades y siempre se ha ido filtrando una cierta influencia desde las ciudades a las aldeas, las cuales en ocasiones han quedado totalmente inmersas en esa influencia ${ }^{2} »$. Debemos tener en cuenta estas palabras sobre todo a la hora de juzgar un repertorio musical como el nuestro, en el que pese a las diferencias de cada país, de cada región, de cada provincia, su música folklórica participa de un fondo estilístico común. Casi todas las músicas populares presentan importantes analogías con las músicas cultas de sus respectivos países. Y en Europa, en donde la imprenta proporcionó un método singularmente bueno y rápido de difusión tanto para el texto de las canciones como para la música que las acompañaba, esta relación ha sido particularmente estrecha.

Hay quien cree que los estilos de nuestra música folklórica constituyen un legado de épocas anteriores a la cultura europea — prehistóricas incluso, legado que evolucionó hasta llegar a un estado semejante al que tiene en la actualidad mucho antes de que una tradición musical culta empezara a influir en el folklore. (¿Cuántas veces se ha echado mano de, por ejemplo, la «tesis celta», la «orientalista», o la «arábigo-andaluza» para hablar del origen, evolución e influencias de la música popular asturiana?). No hay posibilidad de demostrar ni de refutar nada — «rara vez es posible reconstruir la historia musical de una cultura basándose solamente en su tradición oral ${ }^{3}{ }$ - , pero es más seguro creer que los diversos estilos que configuran la música folklórica euro-

\footnotetext{
${ }^{1}$ Josep Martí I Pérez, «Hacia una antropología de la música», Anuario Musical, 47, 1992, págs. 195225, pág. 201.

${ }^{2}$ Bruno NetTL, Música folklórica y tradicional de los continentes occidentales, Madrid, Alianza Editorial, 1985, pág. 20.

${ }^{3}$ Ibídem, pág. 19.
} 
pea comenzaron a fraguarse en algún momento de la Edad Media y que ello fue, hasta cierto punto, consecuencia de la influencia que ejercía una tradición musical culta que también se estaba desarrollando en aquel momento. Sería una forma de explicar el considerable grado de homogeneidad que presenta la música folklórica europea, pero...

Pero realmente es muy poco lo que sabemos sobre la historia de nuestra música popular. Sólo comparándolo con el actual podemos hacernos una idea del repertorio de temas que debieron integrar el cancionero musical de la lírica popular de otros siglos. Desconocemos prácticamente todo de los sonadores tradicionales utilizados en otras épocas (salvo unos cuantos nombres). Apenas sabemos nada de la antigüedad de algunos bailes y canciones, como, por ejemplo, si formaban parte de la tradición folklórica o provenían de la artística (aunque la literatura costumbrista nos pueda echar una mano al respecto). Sabemos también muy poco sobre la edad de los diversos estilos de música folklórica europea...

Con todo, estamos seguros de que ha habido durante siglos una relación estrecha entre la música culta y la música folklórica en este continente. No podía ser de otra forma. Pueblos y ciudades no podían vivir sin cierto contacto recíproco, y pese a que, como señala Nettl, es prácticamente imposible reconstruir la historia musical de una cultura basándose solamente en su tradición oral, son muchos los datos — algunos vamos a desgranarlos a continuaciónque permiten suponer la existencia de una relación constante entre el músico folklórico y su homólogo cortesano, y por tanto una evolución, rápida o lenta, que trajo como consecuencia cambios en el repertorio, en los usos de la música y en las actitudes respecto de ésta. Y todo ello sin perder de vista que en su época - en cualquier época- la música folklórica es a un tiempo antigua y moderna, representativa de viejas tradiciones e indicadora de nuevos gustos, fruto del interés de una o unas pocas personas y, a la vez, del gusto de la mayoría.

La Europa del dieciocho es la primera que desarrolla una conciencia histórica de sus tradiciones musicales. Es el momento en el que se publican numerosas colecciones de poesías y canciones tradicionales, principalmente en las Islas Británicas. En Alemania, Herder fue uno de los primeros en teorizar sobre el origen, naturaleza y distribución de estas canciones populares, excelente caldo de cultivo para el sentimiento nacionalista de mediados del siglo XIX, que alumbraría docenas y docenas de cancioneros cuyo fin era «salvar del naufragio» los restos de un patrimonio musical que se sabía amenazado de muerte. Con más voluntad que preparación, sus autores pusieron las primeras piedras de la ciencia del folklore musical. 


\section{El «Folklore Literario»}

El Proyecto de Investigación Coordinado de la Dirección General de Política Científica en el que trabajé durante dos años — «Música y Fiesta Barroca en España ${ }^{4}$ - me permitió, aunque no con la profundidad que me hubiera gustado, abordar el estudio de la historia de nuestra música tradicional desde, quizá, la única forma que tenemos de hacerlo, y que es el análisis de las referencias a esta conducta en las fuentes literarias del pasado: del dieciocho en este caso. Mi interés o atención por el tema data de la primera lectura de los textos de Guichot y Sierra, López Chávarri, Navascués, Subirá..., y los de quienes desde la antropología o la musicología intentaron algo que, por entonces, entusiasmaba a un aprendiz de profesor de Etnomusicología y folklore.

Noticia histórica del folklore. Orígenes en todos los países hasta 1890. Desarrollo en España hasta 1921, es el título de la obra más célebre de Alejandro Guichot y Sierra; se publicó al año siguiente en Sevilla por Hijos de Guillermo Álvarez, Impresores ${ }^{5}$. Guichot y Sierra dedicó su trabajo «A la memoria del benemérito fundador del Folklore Español, Antonio Machado y Álvarez», con cuya empresa se sentía especialmente identificado y a la que, como investigador del saber popular, dedicaría un considerable esfuerzo. De la obra de Alejandro Guichot y Sierra nos interesa sólo algún apartado del capítulo II de la $2^{\mathrm{a}}$ parte, como por ejemplo el consagrado a «cantares» y «diversiones públicas» (págs. 139-141): «Es el período más extenso, que empieza no mucho después de la formación de las literaturas nacionales y de las sociedades modernas en el siglo XIII, y llega hasta el término del siglo XVIII con el neoclasicismo. Separados lo erudito y lo popular, esta producción tradicional estaba desconsiderada; se la tenía como cantera sin dueño, y hasta como fruto colectivo sin valor cotizable. Así, el autor erudito se apoderaba la producción tradicional, la obra popular oral, la modificaba, la utilizaba a su gusto y a su fin y, como elemento desdeñado, la ocultaba en la mezcla. Es ésta una labor cómoda y provechosa para el trabajo y la inspiración individual erudita; sus fines son subjetivos de egoísmos literario y artístico; pudiendo llamarse a este largo período, por tanto, de los utilizadores egoístas ${ }^{{ }}$.

Joaquín $\mathrm{M}^{\mathrm{a}}$ de Navascués fue autor de un notable y encendido «boceto histórico» de lo popular, titulado «El folklore español». Vio la luz en el pri-

\footnotetext{
${ }^{4}$ Proyecto de Investigación del Programa Sectorial de Promoción General del Conocimiento N ${ }^{\circ}$ PB97/1340/C04/03.

${ }^{5}$ Alejandro Guichot y Sierra, Noticia histórica del folklore. Orígenes en todos los países hasta 1890. Desarrollo en España hasta 1921, por..., Sevilla, Hijos de Guillermo Álvarez, Impresores, 1922.

${ }^{6}$ Ibídem, pág. 12.
} 
mero de los tres volúmenes de la obra de Francisco Carreras y Candi, Folklore y costumbres de España, una de las grandes realizaciones editoriales del «Modernismo antropológico» catalán —así definió Luis Calvo al período comprendido entre 1900 y $1936^{7}$ — junto al Arxiu de tradicións populars, de Serra i Boldú, y la monumental Biblioteca de tradicions populars, de Joan Amades. La primera edición de la obra de Carreras y Candi, publicada en Barcelona por Alberto Martín, data de $1931^{\circ}$. Del trabajo de Navascués — de más de un centenar y medio de páginas - nos interesa especialmente el capítulo dedicado al siglo XVIII, en el que el autor pasa revista a diversos textos de Francisco Asensio, Feijoo, Moratín, Jovellanos, Afán de Ribera y Ramón de la Cruz?

Contra la opinión de Alejandro Guichot y Sierra, Navascués estaba empeñado en demostrar que «los trabajos folklóricos son anteriores a la invención del Folklore ${ }^{10} \gg$ y que ésta era una ciencia que en nuestro país contaba con una larga tradición y no sólo con «precedentes a los orígenes ${ }^{11}$ », máxime «cuando las obras de algunos de ellos no han sido superadas en la actualidad folklorica ${ }^{12}$ ». De ahí la gran cantidad de páginas que Navascués dedica a la «historia subjetiva del folklore español», o «folklore literario», en su trabajo: «La ciencia de Folklore no ha sido realmente instituida. Se ha pretendido que lo fue con la fundación de la Folklore Society, como si la institución de una ciencia dependiese de la constitución de una entidad social. Mucho antes de la fundación inglesa, en casi todos los países en que a partir de entonces se notó más profundamente el movimiento folklorista, había habido cultivadores de lo que se pretende pasar por nuevo, siendo de notar que el país menos abundante en trabajos de esta índole fue Inglaterra' ${ }^{13}{ }$.

\footnotetext{
${ }^{7}$ Luis Calvo i Calvo, «Folclore, etnografía y etnología en Cataluña», en Ángel Aguirre Baztán (ed.), Historia de la antropología española, Barcelona, Boixareu Universitaria, 1992, págs. 207-240, págs. 216-226.

${ }^{8}$ F.[Francisco] Carreras y Candi (dir.), Folklore y costumbres de España, Barcelona, Casa Editorial Alberto Martín, 1943-1946, 3 vols. [vol. I, 1943, copyright 1931, impresor Tip. Altés; vol. II, 1944, copyright 1944, impresor Ponsa; vol. III, 1946, copyright 1934, impresor Ponsa]. Aunque F. Carreras y Candi no puso fecha al «Prólogo» que redactó para la obra (vol. I, págs. v-x), parece que fue escrito a comienzos de la década de los 20 — No es ahora nuestro ánimo, apunta, ni prejuzgar discusiones no falladas, ni menos prescindir de la historia [...] al iniciarse el tercer decenio del siglo xx» (pág. vI)— y sin estar concluido el trabajo, pues da nombres de colaboradores que finalmente no firmaron capítulo alguno de los volúmenes de la publicación, como Francisco Rodríguez Marín, Ramón Menéndez Pidal, Juan Moneva y Puyol, Tomás Carreras y Artau, Luis de Hoyos o Julio de Apraiz. Decir de paso que las colaboraciones de Eduardo M. Torner, «La canción tradicional española» (vol. II, págs. 5-166), y Aurelio Capmany, «El baile y la danza» (vol. II, págs. 167418), contienen, igualmente, numerosas alusiones a la música popular de otras épocas.

${ }^{9}$ Joaquín Ma de Navascués, «El folklore español. Boceto histórico», por..., en Carreras y Candi, Folklore y costumbres de España, vol. I, págs. 1-164, págs. 85-106.

${ }^{10}$ Ibídem, págs. 19 y sigs.

${ }^{11}$ Guichot y Sierra, Noticia histórica del folklore, págs. 133-143.

12 Navascués, «El folklore español», pág. 30.

${ }^{13}$ Ibídem, pág. 22.
} 
«Guichot, folklorista consecuente y amigo de Antonio Machado y Álvarez, despreciando todo el trabajo folklórico español anterior al año 1881, considera que no comienza la historia del Folklore en España hasta que Machado fundó el Folklore Español, en 3 de noviembre de aquel año. Guichot — termina Joaquín $\mathrm{M}^{\mathrm{a}}$ de Navascués- es un folklorista fiel y devoto de la nueva ciencia, y cualquier fetiche de ella halla más eco en su opinión que la evidencia de una realidad ${ }^{14}$ ». Este texto, tomado del «Boceto histórico» de Navascués, deja muy claro lo que pretende éste y, de alguna manera, lo que había hecho aquél. Si en el libro de Alejandro Guichot y Sierra se pone el acento en el rigor científico de los trabajos emprendidos con posterioridad a la fundación del Folklore Español — tildando de «diligentes», «amantes» y hasta de «fieles» a lo popular las labores efectuadas hasta entonces (nunca de «folklóricas»)—, el empeño del segundo es justo el contrario: subrayar el carácter «folklórico» de los trabajos anteriores «a la invención del Folklore». En dicha tarea Navascués invierte la mayor parte de las páginas de su «Boceto», agrupando el paciente recuento de obras y autores que lleva a efecto en dos grandes apartados: «folklore literario» $\mathrm{y}$ «folklore figurado».

Entre las historias de la música española de no más acá de mediados del siglo pasado, la de José Subirá — de 1953—, es de las que más trata el tema del folklore. Lo hace en el capítulo primero de la tercera parte — «La música popular en España e islas adyacentes»— y desde un punto de vista histórico, que es el que ahora nos preocupa, al hablar de «literatura filarmónica» en diversos capítulos de la primera y segunda partes del libro ${ }^{15}$. Finalmente, el manualillo Música popular española, de López Chávarri — tan singular—, es más un intento de trazar una historia de la música popular española - y por eso lo traigo aquí- que un estudio o aproximación al folklore musical de su tiempo —el libro se publicó en $1927^{16}$ —.

En 1903, el Establecimiento tipográfico «Sucesores de Rivadeneyra» publicó la obra más célebre de Jenaro Alenda y Mira: Relaciones de solemnidades y fiestas públicas de España, que había sido premiada por la Biblioteca Nacional en $1865^{17}$. Dividida en dos volúmenes, Relaciones es un catálogo —el más famoso sin duda — de fiestas urbanas y acontecimientos familiares que originaron cele-

\footnotetext{
${ }^{14}$ Ibídem, pág. 25.

${ }^{15}$ José Subirá, Historia de la música española e hispanoamericana, Barcelona, Salvat, 1953, págs. 883936 y $607-622$.

${ }^{16}$ Eduardo López Chávarri, Música popular española, Barcelona, Labor, 1927. De él interesan algunos epígrafes del capítulo VIII, titulado «La música popular y el teatro», págs. 83-93.

${ }^{17}$ Jenaro AlENDa y MiRa, Relaciones de solemnidades y fiestas públicas de España, por don... Obra premiada por la Biblioteca Nacional en el concurso público de 1865 é impresa á expensas del Estado, Madrid, Establecimiento tipográfico Sucesores de Rivadeneyra, 1903, 2 vols.
} 
braciones de renombre. Alenda parecía un hombre minucioso que llevaba su tesón a transcribir las cosas más singulares de las relaciones que anota y, algunas veces, comenta. Obras como la suya nos brindan la oportunidad de reconstruir con relativa precisión el marco de la celebración festiva, en el que la música tiene tanta importancia ${ }^{18}$. Pero, claro está, el de las fiestas urbanas, porque de las que tenían lugar en las aldeas (como las de carnaval, marzo y mayo, estío, bodas u otras celebraciones familiares en las que no podía faltar la música) apenas sabemos nada porque no contaron con reporteros oficiales al estilo de las áulicas. Estas descripciones constituyen una fuente muy importante para el conocimiento de la música popular de otras épocas — y por eso las traigo aquí-, pero conviene no perder de vista que la pasión notarial de sus redactores por «reconstruir con precisión el tiempo y espacio de la fiesta ${ }^{19}{ }$ nunca fue tal. Era literatura — de mayor o menor interés - al servicio de quien la pagaba. Al servicio de quien costeaba no sólo su redacción sino, sobe todo, su difusión — costosa y con privilegios varios- - Y con estas salvedades hay que tomarla.

Para conocer este tipo de celebraciones — con las que «también se divierte el pueblo» que diría Deleito y Piñuela ${ }^{20}$ — resulta imprescindible repasar atentamente el «folklore literario» del tiempo; un proceder que está en la base de algunos de los mejores trabajos de Caro Baroja en el ámbito de la antropología cultural $^{21}$, o Frenk Alatorre en el de la literatura popular ${ }^{22}$; y que tuvo en Cotarelo y Mori un verdadero maestro: «para obtener, pues, algo de provecho sobre nuestros antiguos bailes —escribe- hay que acudir á los textos literarios de novelistas, poetas, moralistas, escritores de costumbres y otros; tarea larga y difí-

\footnotetext{
${ }^{18}$ En este orden de cosas también resulta muy útil la obra de Natividad Moreno Garbayo, Catálogo de los documentos referentes a diversiones públicas conservados en el Archivo Histórico Nacional, por..., Madrid, Dirección General de Archivos y Bibliotecas, [1958].

${ }^{19}$ José María Dítz Borque, «Relaciones de teatro y fiesta en el Barroco español», en Teatro y fiesta en el Barroco. España e Iberoamérica. Seminario de la Universidad Internacional Menéndez Pelayo. Sevilla, octubre de 1985, Barcelona, Ediciones del Serbal, 1986, págs. 11-40, pág. 39n.

${ }^{20}$ José Deleito y Piñuela, El rey se divierte y ...también se divierte el pueblo, Madrid, Alianza Editorial, 1988.

${ }^{21}$ Julio Caro Baroja, El Carnaval. (Análisis histórico-cultural); El estío festivo. (Fiestas populares del verano) y La estación de amor. (Fiestas populares de mayo a San Juan), Barcelona, Círculo de Lectores, 1992.

${ }^{22}$ Margit Frenk, «Dignificación de la literatura popular en el Siglo de Oro», en Estudios sobre lírica antigua, Madrid, Castalia, 1978, págs. 47-80; ídem, «Plenitud literaria de la canción popular», en Francisco Rico, Historia y crítica de la literatura española, III. Siglos de Oro: Barroco, por Bruce W. Wardropper y otros (al cuidado de Bruce W. Wardropper y Aurora Egido, Luciano García Lorenzo, Pablo Jauralde Pou, Miguel Ángel Pérez Priego, Juan Manuel Rozas, Gonzalo Sobejano, Carlos Vaíllo, Domingo Ynduráin), Barcelona, Editorial Crítica, 1983, págs. 95-99; ídem, Corpus de la antigua lírica popular hispánica (siglos XV a XVII), colab. téc. John Albert Bickford y Kathryn Kruger-Hickman, Madrid, Editorial Castalia, 1987; e ídem, "La literatura oral», en Francisco Rico, Historia y crítica de la literatura española, 3/1. Siglos de Oro. Barroco. Primer suplemento, por Aurora Egido y otros (al cuidado de Carlos Vaíllo), Barcelona, Editorial Crítica, 1992, págs. 49-55.
} 
cil para que nadie la emprenda de propósito ${ }^{23}{ }_{»}$. Me acerqué al tema en la ponencia que presenté al congreso Música y Fiesta Barroca en Castilla y León, que tuvo lugar en Salamanca a finales de 1999 y que titulé «El sonido y la palabra: residuos de la música popular en las fuentes literarias del Barroco $^{24}$ », y un año después en mi comunicación al V Congreso de la Sociedad Española de Musicología, que llevaba por título «La música popular y el folklore literario: el siglo xVIII ${ }^{25}$ » y que me ha servido de base para la redacción del presente artículo.

Proponemos un acercamiento al folklore musical del dieciocho español a través de la literatura. No son pocos los textos de la centuria que directa o indirectamente pintan usos y costumbres en los que la música desempeña un papel importante. Los casos de Jovellanos (Espectáculos y diversiones públicas; Cartas del Viaje de Asturias), Feijoo (Theatro crítico universal), Casanova (Memorias de España), Valladares de Sotomayor (Colección de seguidillas o cantares), Iza Zamácola y de Ozerín (Colección de las mejores coplas de seguidillas), Ramón de la Cruz (Las provincias españolas unidas por el placer) o Torres Villarroel (Visiones y visitas de Torres con D. Francisco de Quevedo por la Corte) constituyen magníficos ejemplos de una «literatura filarmónica» que profundiza en la pintura de la música de su tiempo, su lectura resulta imprescindible si «de propósito» —que diría Cotarelo y Mori- queremos construir la historia de nuestro folklore musical.

\section{Gaspar Melchor de Jovellanos}

Debe ser Jovellanos (1744-1811) la figura más citada de su siglo a este respecto. No falta su nombre ni en el texto de Navascués ${ }^{26}$ ni en el de Guichot y Sierra ${ }^{27}$, como cabría esperar. La obra que citan ambos es la Memoria para el arreglo de la policía de los espectáculos y diversiones públicas, y sobre su origen en España, que el Consejo de Castilla encargó a la Academia de la Historia en 1786 y ésta al polígrafo gijonés, que trabajó en ella cuatro años ${ }^{28}$.

${ }^{23}$ Emilio Cotarelo y Mori, Colección de entremeses, loas, bailes, jácaras y mojigangas desde fines del siglo XVI á mediados del XVIII. Ordenada por... de la Real Academia Española, Madrid, Casa Editorial Bailly-Bailliére, 1911, 2 vols., vol. I, pág. ccxxix.

${ }^{24}$ José Antonio Gómez Rodríguez, «El sonido y la palabra: residuos de la música popular en las fuentes literarias del Barroco», en Actas del Coloquio Música y Fiesta Barroca en Castilla y León. Universidad de Salamanca, 2 y 3 de diciembre de 1999, en prensa.

${ }_{25}$ Ídem, «La música popular y el «folklore literario»: el siglo xvII", en Actas del V Congreso de la Sociedad Española de Musicología, «Campos interdisciplinares de la musicología». Barcelona, 25-28 de octubre de 2000, Madrid, Sociedad Española de Musicología, en prensa.

${ }^{26}$ NAVASCUÉs, «El folklore español», págs. 97-100.

${ }^{27}$ Guichot y Sierra, Noticia histórica del folklore, págs. 140-141.

${ }^{28}$ Gaspar Melchor de JovelLanos, Espectáculos y diversiones públicas. Informe sobre la Ley Agraria, ed. José Lage, Madrid, Ediciones Cátedra, 1979²". 
Al comienzo de la segunda parte de la obra, Jovellanos divide al pueblo en dos clases: «una que trabaja y otra que huelga ${ }^{29}{ }_{»}$; las diversiones son características de la primera, los espectáculos de los que viven de sus rentas. Al tratar del «Origen general de las diversiones y espectáculos en España» — primera parte de la Memoria - Jovellanos describe, entre otros asuntos, una de las principales diversiones de quienes «subsisten del producto de su trabajo diario»: las «romerías», "cuyo origen se pierde en los tiempos de la primitiva fundación de todos los pueblos», dice. Y refiriéndose a las danzas que tienen lugar en ellas, comenta que la mayor parte «son tan sencillas y ajenas de artificio que indican un origen remotísimo y acaso anterior a la invención de la gimnástica»:

En esta época, sin duda, creció y se fomentó el gusto de las romerías, cuyo origen se pierde en los tiempos de la primitiva fundación de todos los pueblos. [...] Si no se introdujeron, por lo menos es de sospechar que en este tiempo se propagaron el uso y la afición a nuestras danzas populares. La mayor parte de ellas son tan sencillas y ajenas de artificio que indican un origen remotísimo y acaso anterior a la invención de la gimnástica. Empero hay muchas que una cuidadosa observación pudiera, por su forma y enlaces, atinar con la época de su establecimiento, y entonces sin duda se hallaría coincidiendo con la que hemos determinado*. Importa poco esta averiguación; harto más importa la observación de que existen muchos pueblos todavía que, preservados de la infección del vicio, no reconocen otro recreo que estas alegres concurrencias y los inocentes juegos y danzas que hacen en ellas su delicia.

* Consérvanse aún en el país en que escribo dos danzas que pueden confirmar lo dicho en el texto, conocidas por los nombres de danza de romeros y danza de espadas. El nombre de la primera, y la esclavina, bordón y calabaza con que se adornan sus danzantes, indican bastante su origen; y siendo bien conocido en la historia el tiempo en que empezaron y crecieron las peregrinaciones a San Salvador de Oviedo, tampoco parece difícil determinar su época. La de la segunda, que sin duda es de más antiguo y noble origen, puede inferirse de su forma. Todas sus mudanzas o evoluciones terminan en una rueda, en que los danzantes, teniendo recíprocamente sus espadas por la punta y pomo, forman la figura de un escudo. Formada, sube en él el caporal o guión de la danza y, alzado por sus camaradas en alto y vuelto en torno a los cuatro puntos principales del mundo, hace con su espada ciertos movimientos, como en desafío de los enemigos de su gente. Los

${ }^{29}$ Ibídem, pág. 117. 
que saben la fórmula de la elevación de los reyes visigodos poco trabajo tendrán en atinar con el origen, o por lo menos con el tipo, de esta danza.

Jovellanos, Espectáculos y diversiones públicas, págs. 80-81.

La primera noticia de la «danza de romeros» de Pola de Siero (Asturias) - una anotación en los libros de la antigua cofradía de Nuestra Señora del Carmen - data del siglo XVIII, pero nada parece que tenga que ver esta danza de arcos — descrita a comienzos del siglo pasado por Fausto Vigil ${ }^{30}$ y más modernamente por Luis Argüelles ${ }^{31}$ _ con la que menciona Jovellanos ${ }^{32}$. Por lo que respecta a la de espadas — que Felipe Rojo de Flores denomina Ballimachia o Lucha de las espadas en su célebre Tratado de recreación ${ }^{33}$ _, cabe recordar que tiene una larga tradición en España, muy ligada a la festividad del Corpus y con testimonios tan notables como los de Mateo Alemán ${ }^{34}$, Covarrubias ${ }^{35}$ o Cer-

${ }^{30}$ Fausto Vigit, «La danza de romeros», La tierrina, Oviedo, 1909, págs. 63-64.
${ }^{31}$ Luis ArgüElles, «La Danza de los Romeros de Pola de Siero», El Comercio, Gijón, 10 de febrero de 1984.

${ }^{32}$ La de Pola de Siero era una danza de arcos similar a la que se ejecutaba en otras localidades asturianas, como Ribadesella o Llanes, vid. Yolanda CERRA BADA, Bailes y danzas tradicionales en Asturias, Oviedo, Instituto de Estudios Asturianos, 1991, págs. 120-124. Sería extraño que Jovellanos hubiera pasado por alto este elemento al referirse a la que llama «danza de romeros».

${ }^{33}$ Felipe Rojo de Flores, Tratado de recreación instructiva sobre la danza. Su invención y diferencias. Dispuesto por D...., Madrid, Imp. Real, 1793 [reed. Madrid, V. Vindel, 1929].

${ }^{34}$ En Guzmán de Alfarache [1599 y 1604] 1ª II, 7, vid. Mateo Alemán, Guzmán de Alfarache, ed. Francisco Rico, Barcelona, Planeta, 1983, pág. 316:

Y pareciéndome que todo estaría seguro para poder mudar el rancho y marchar, hice un pequeñuelo lío de los forros viejos que del sayuelo me quedaron, donde metí envuelta la sangre de mi corazón. Quedóme sólo el viejo lienzo de los calzones, un juboncillo desarrapado y una rota camisa; pero todo limpio, que lo había por momentos lavado. Quedé puesto en blanco, muy acomodado para la danza de espadas de los hortelanos.

${ }^{35}$ En el Tesoro [1611], vid. Sebastián de Covarnubias, Tesoro de la lengua castellana o española, ed. Martín de Riquer, Barcelona, Alta Fulla, 19892a, págs. 442-443:

DANÇA DE ESPADAS. Esta dança se usa en el reyno de Toledo, y dánçanla en camisa y en gregescos de lienço, con unos tocadores en la cabeça, y traen espadas blancas y hazen con ellas grandes bueltas y rebueltas, y una mudança que llaman la degollada, porque cercan el cuello del que los guía con las espadas, y quando parece que se la van a cortar por todas partes, se les escurre de entre ellas. Esta dança llamaron los griegos xijismoV, saltatio quaedam cum ensibus, de xijoV, to, ensis, y otros la llaman ballimachia, ballimacia, a verbo ballixw et maci, pugna, que es lo mismo que pyrrichia. La dança de Orgaz, no estoy cierto por qué se dixo; sé que unos lugares tienen con los otros vezinos ciertas maneras de pullas, burlándose unos con otros, como el que dizen de echa caldo a los de Orgaz y por donde va la dança, del dançante que, acompañando la fiesta y procesión del Corpus Christi, entró a beber en una taberna, y de cansado y bien bevido se durmió y no despertó hasta otro día; y pareciéndole que no avía sido sueño, sino una traspuesta de un credo, salió preguntando: ¿Por dónde va la dança? El hazer danças en las fiestas del Señor, es antiguo, desde el tiempo de David, que dançó delante del arca del Señor, aunque a su muger Micol le pareció descompostura, y refiere el padre Pineda en su Monarquía, lib. 3, cap. 22, § I, que los que bailaron en la dedicación y procesión del Arca del Testamento, no sintieron cansancio. Vide supra, verbo baylar. 

había herido alguno de los danzantes.

- Por ahora, bendito sea Dios, no se ha herido nadie: todos vamos sanos.

Y luego comenzó a enredarse con los demás compañeros, con tantas vueltas y con tanta destreza, que aunque don Quijote estaba hecho a ver semejantes danzas, ninguna le había parecido tan bien como aquella.

Y en La tía fingida, vid. Miguel de Cervantes SaAvedra, Novelas ejemplares, III, ed. Juan Bautista Avalle-Arce, Madrid, Editorial Castalia, 1982 $2^{3^{a}}$, págs. 355-356:

Estando en este deporte y conversación con la repulgada dueña del huy y las perlas, venía por la calle gran tropel de gente, y creyendo los músicos y acompañados que era la Justicia de la ciudad, se hicieron todos una rueda, y recogieron en medio del escuadrón el bagage de los músicos; y como llegase la Justicia, comenzaron a repicar los broqueles y crujir las mallas, a cuyo son no quiso la Justicia danzar la danza de espadas de los hortelanos de la fiesta del Corpus de Sevilla, sino pasó adelante, por no parecer a sus ministros, corchetes y porquerones aquella feria de ganancia.

${ }^{37}$ Aurelio Capmany, «El baile y la danza», por..., en Carreras y Candi, Folklore y costumbres de España, vol. II, págs. 167-418, págs. 398 y sigs., aporta también el testimonio de Juan Moraleda y Esteban, Seises de la Catedral de Toledo, donde dice que «esta danza era la más comprometida, pues hacían los danzantes alarde de manejar las espadas con agilidad y donaire singulares. Simulaban asaltos de esgrima, adoptaban posturas y situaciones arriesgadas. Unas veces se acosaban cuatro a cuatro, otras dos a dos, y a veces lucíanse solos». Igualmente, Capmany halla mencionada esta danza en las crónicas de los festejos que la ciudad de Valencia dedicó al rey Don Juan II en 1459, en las fiestas que la ciudad de Burgos dedicó en 1570 a la Reina con ocasión de su casamiento con Felipe II y en las que tuvieron lugar en Madrid en 1657 con motivo del nacimiento del Príncipe. Cotarelo y Mori, Colección de entremeses, vol. I, págs. ccxliI-CcxliII, señala que en el baile del Amor espadero, de Francisco Benegasi y Luján (fines del siglo XVII) se dice: «Se dará fin con una danza de espadas, ejecutada con el mayor primor que puedan». Caro Baroja, El estío festivo, págs. 125138, dedica un capítulo entero, el séptimo, a «las danzas de espadas y los paloteados en los textos españoles antiguos», apuntando otras referencias, como la que aparece en La gran conquista de ultramar al describir el recibimiento que hicieron los de Oliferma a Corvalán; Vicente Espinel, en el descanso primero de la segunda parte de la Vida de Marcos de Obregón; Gonzalo Correas, en la sección de frases de su Vocabulario de refranes y frases proverbiales; Lope de Vega, en el acto I de Los amantes sin amor; o en autores tales como Caro o Alderete. En el siglo xix aludirán a esta danza Basilio Sebastián de Castellanos, en sus Discursos históricoarqueológicos sobre el origen, progresos y decadencia de la música y baile español, Madrid, 1854, págs. 880881, y el barón Charles Davillier en su Viaje por España. Aquél la relaciona con un tipo de danza de moros y cristianos, y éste, tras hacerse eco de los textos de Covarrubias y Cervantes y señalando que era Toledo el reino donde más extendida estaba esta danza, «probablemente a causa de la mucha fama que tenía este país respecto a la fabricación de armas blancas», dice que «se ha abandonado desde hace mucho tiempo», pero que permanece en el recuerdo, porque «cuando quiere hablarse de una disputa familiar todavía se dice hoy: “Es una danza de espadas!””, vid. Gustave Doré, y Barón Ch.[Charles] Davillier, Viaje por España, Madrid, Anjana Ediciones, 1982, 2 vols., págs. 476-477.

38 «Sobre la antigüedad de esta danza vasca — anota CAPMANY, «El baile y la danza», pág. 400— se conocen unas Ordenanzas del año 1486, hechas en Vitoria, que prescriben: "se castigará con la multa de sesenta 
cias de ella a finales del siglo XVIII. En su recorrido por el teatro escolar de este siglo, Jesús Menéndez Peláez reproduce la Descripción breve de las fiestas que hizo la Ciudad de Oviedo, con los plausibles motivos del feliz Nacimiento de los Infantes Gemélos, Carlos, y Felipe de Borbón, y ajuste de la Paz con la Gran $B r e t a \tilde{n} a^{39}$, en donde leemos que «En esta misma tarde hizo el Gremio de Texedores su arriesgada danza de Espadas con tal ayre y gala y con tan ayrosas figuras que á muchos espíritus hijos de Marte, de que abunda el País, llebava los ojos con todas sus atenciones este vivo recuerdo de los antiguos Gladiatores Romanos; dexándose poseer de representaciones, los que nunca se dexaron conquistar de su esfuerzo y fortuna ${ }^{40}$ ». «La danza primaveral o veraniega se asocia de tal forma al Corpus que bien puede decirse que no hay Corpus sin danzas $^{41}{ }_{»}$. Con el paso del tiempo, las más características se desprendieron de él, como pasó en Llanes, donde el gremio de mareantes sufragaba las danzas de espadas en diversas festividades (Santa Ana, Corpus, Nuestra Señora, San Roque, La Guía ${ }^{42}$ ). Organizarlas, fuera en ciudades o aldeas, era mucho más factible que montar otro tipo de espectáculos más costosos, pero con el transcurso del tiempo las danzas del Corpus sufrieron una evolución funcional que las independizó de esta celebración festiva. Las de espadas y las de palos eran las más célebres y, por dicho motivo, llegaron a ejecutarse por cualquier motivo social ${ }^{43}$.

maravedises a los que hiciesen danzas de espadas, por los escándalos y derramamiento de sangre que ocasionaban con ellas"». Menciona el hecho Curt SACHS, Historia universal de la danza, Buenos Aires, Centurión, 1944, pág. 123, aunque, como señala Juan Antonio Urbeltz Navarro, Dantzak. Notas sobre las danzas tradicionales de los vascos, pres. Luis Iriondo Etxaniz, intr. Ninette de Valois, pref. Lucile Armstrong, Bilbao, Caja Laboral popular, 1978, págs. 109-145, de manera equivocada.

${ }^{39}$ Impreso en Oviedo por Francisco Díaz Pedregal en 1784.

${ }^{40}$ Jesús Menéndez Peláez, Teatro escolar en la Asturias del siglo xviI, Gijón, G.H. Editores, 1986, pág. 71. En la segunda página del manuscrito se describe el pasacalle musical que, previo a la Loa, se había llevado a efecto por la mañana: «Destinóse el dia 29 de Diciembre de 83 para dar principio á la primera iluminacion, y à las doce de este dia, con un general repique de Campanas tan acorde que parecian unisonas, rompieron sus voces los Tambores, Clarines, Pifanos, Gaytas y Sinfonìas, que a un tiempo en gran numero con repetidas salvas de fusilería, fueron paseando las Calles principales, con tanto estruendo y alegría, que no se echaron menos la horrísona Artillería, ni la mas agradable concertada musica; pero todo con tanto sosiego y tranquilidad publica, que sobraron todas las precauciones que se habian tomado para evitar desordenes", ibídem, pág. 30. Clarines, caxas... y demás «militares instrumentos» suenan de nuevo en otros momentos de la Descripción, que también da cuenta, hacia la mitad, de «una ingeniosa danza llamada de Palillos» que los niños bailaron «con tanta agilidad y destreza, que era espectaculo admirable a todos por la variedad de mudanzas con que la executavan», ibídem, pág. 65.

${ }^{41}$ Caro Baroja, El estío festivo, pág. 73.

${ }^{42}$ Cerra BaDa, Bailes y danzas tradicionales, págs. 114-115.

${ }^{43}$ SACHS, Historia universal de la danza, págs. 55, 131 y 261, aborda el tema de la danza de espadas en distintos apartados de su célebre tratado. Destaca en ella la destreza de sus participantes: «un grupo de jóvenes solteros, miembros en su mayoría de un gremio particular [...]»; y sobre su significado dice que «no es sólo una estilización danzada de la batalla, sino que une los dos poderes que promueven el crecimiento, el negativo (defensivo) y el positivo (fálico). Por eso el color blanco de las vestimentas, el tiznado del rostro, los cascabeles, la figura del bufo, las escenas de "muerte y despertar" y finalmente, el entrecruzamiento de 
Músicas, bailes y danzas salen otras muchas veces a relucir en la Memoria de Jovellanos. Así, al tratar de la «Historia particular de los espectáculos» se mencionan instrumentos diversos, tales como cuernos, atabales, bocinas y trompetas (a propósito de la caza), añafiles y tambores (de los torneos) y «numerosas cuadrillas de trovadores y juglares, menestriles y tañedores de instrumentos» (al tratar de las fiestas palacianas). Se aborda, igualmente, el tema del baile y la danza: «A todo esto sucedía y ponía fin el baile, que, alternando con la conversación y con la música, se prolongaba, como en nuestros días, por la alta noche. Danzábase ya entonces entre damas y caballeros; danzábase de uno a uno o de más a más y se danzaban bailes de enlace y maestría, en que la moda, a lo que se puede colegir de sus varios nombres y tonos, iba introduciendo cada día nuevos artificios y usanzas extranjeras. Que también entonces como ahora, y en esto como en más graves cosas, los hombres, siempre inestables y livianos, miraban con hastío lo conocido y se perecían por lo raro y lo nuevo ${ }^{44}{ }$. Se trata de zaharrones y remedadores, mayas y diablillos, moharrilas, botargas y «otros extravagantes personajes de que se halla mención en nuestras antiguas memorias pertenecientes al arte mímica». Y, en fin, se habla de una música «reducida primero a la guitarra y al canto de algunas jácaras entonadas por ciegos» que luego "admitió el artificio de la armonía, cantándose a tres y a cuatro», y del «encanto de la modulación, aplicada a la representación de algunos dramas, que, del lugar en que más frecuentemente se oían, tomaron el nombre de zarzuelas».

En la segunda parte de la Memoria, Jovellanos aborda de nuevo el tema de las romerías para condenar el abuso de los reglamentos de policía: «Se ha prohibido en ellas el uso de los palos, que hace aquí necesarios, más que la defensa, la fragosidad del país; se han vedado las danzas de hombres, se ha hecho cesar a media tarde las de mujeres, $y$, finalmente, se obliga a disolver antes de la oración las romerías, que son la única diversión de estos laboriosos e inocentes pueblos ${ }^{45}$. La primera de las dos últimas referencias importantes a la música

\footnotetext{
las hileras de danzarines son todas características indiscutibles de una ceremonia de vegetación». Marius Schneider, discípulo de Sachs y autor de un par de trabajos sobre el tema, abunda en dicha significación: Marius Schneider, «La danza de espadas y la tarantela», Anuario Musical, 2, 1947, págs. 41-51, e ídem, La danza de espadas y la tarantela. Ensayo musicológico, etnográfico y arqueológico sobre los ritos medicinales, Barcelona, Instituto Español de Musicología del C.S.I.C., 1948. Para el que fuera responsable de la Sección de Folklore del Instituto Español de Musicología hasta 1955, «los ritos medicinales llevaban espadas, lanzas, látigos o garrotes, los cuales constituyen el ritmo-símbolo del sacrificio que produce la vida nueva», vid. SCHNEIDER, «La danza de espadas y la tarantela», pág. 42.

${ }^{44}$ Jovellanos, Espectáculos y diversiones públicas, págs. 99-100.

${ }^{45}$ Ibídem. Volverá a referirse Jovellanos a los palos al tratar de la danza prima en su Carta octava a Ponz: «Como quiera que sea, estas danzas varoniles suelen rematar muchas veces en palos, única arma de que usa nuestro pueblo; y como nunca la sueltan, vería usted a todos los danzantes con su garrote al hombro, que
} 
que aquí encontramos, es una nota — la 20 - añadida a la Memoria cuando su publicación, que trata de los bailes dominicales del país vascongado — que Jovellanos pone como ejemplo de los regocijos y diversiones populares «ya habituales, ya periódicos, establecidos por costumbre. Ejercicios de fuerza, destreza, agilidad o ligereza; bailes públicos, lumbradas o meriendas, paseos, carreras, disfraces o mojigangas; sean los que fueren, todos serán buenos e inocentes»y que arroja algo de luz al sombrío panorama trazado por el autor al comienzo de la segunda parte de la Memoria («¿cómo es que la mayor parte de los pueblos de España no se divierten en manera alguna?»):

Cuando escribimos esta Memoria no conocíamos el país vascongado ni sus bailes dominicales; pero un viaje hecho por él en 1791, y repetido en 1797, nos proporcionó el gusto de observarlos, y nos confirmó más y más en lo que habíamos escrito acerca de las diversiones populares. Es ciertamente de admirar cuán bien se concilian en estos sencillos pasatiempos el orden y la decencia con la libertad, el contento, la alegría y la gresca que los anima. Allí es de ver un pueblo entero, sin distinción de sexos ni edades, correr y saltar alegremente en pos del tamboril, asidos todos de las manos, y tan enteramente abandonados al esparcimiento y al placer, que fuera muy insensible quien los observase sin participar de su inocente alegría. Tanto basta para recomendar estas fiestas públicas a los ojos de todo hombre sensible; pero el filósofo verá además en ellas el origen de aquel candor, franqueza y genial alegría que caracteriza al pueblo que las disfruta, y aun también de la unión, de la fraternidad y del ardiente patriotismo que reina entre sus individuos. ¡Cuán fácil no fuera, con sólo extender tan sencillas instituciones, lograr los mismos inestimables bienes en otras provincias! (ibídem, pág. 122).

La segunda es el apartado que dedica a la música y el baile al tratar de los medios para lograr la reforma en los teatros. «Atrapados entre la obligación

$\overline{\text { sostienen con }}$ dos dedos de la mano izquierda, libres los otros para enlazarse en rueda, seguir danzando en ella con gran mesura y seriedad. Sucede, pues, frecuentemente que, en medio de la danza, algún valentón caliente de cascos empieza a victorear a su lugar o su concejo. Los del concejo confinante, y por lo común rival, victorean al suyo; crece la competencia y la gritería, y con la gritería la confusión; los menos valientes huyen; el más atrevido enarbola su palo; le descarga sobre quien mejor le parece, y al cabo se arma tal pelea de garrotazos, que pocas veces deja de correr sangre, y alguna se han experimentado más tristes consecuencias», vid. Gaspar Melchor de Jovellanos, Cartas del Viaje de Asturias. (Cartas a Ponz), ed. José Miguel Caso González, Salinas, Ayalga Ediciones, 1981, 2 vols., vol. II, pág. 34. Las Ordenanzas Municipales de Oviedo decían todavía en 1914: "para evitar todo motivo de disgusto que perturbe el sosiego y la tranquilidad que todos deben apetecer, se prohibe que toda persona que asista a la danza prima, usada en los días festivos y en las romerías, lleve palo u otra cualquiera arma ofensiva», op. cit. por Cerra BADA, Bailes y danzas tradicionales, pág. 95. 
de componer tonadillas casi a destajo [...] algunos músicos españoles luchaban por dignificar un espectáculo que, sobre cualquier otra ventaja, y como el villancico en las iglesias, suponía el más continuado y apreciado contacto con el público ${ }^{46} \gg$. En este aspecto, Jovellanos no hacía otra cosa que recoger las anheladas reformas que algunos músicos abrigaban para su arte:

¿Y qué diremos de la música y el baile, dos objetos tan atrasados entre nosotros y capaces de ser llevados al mayor punto de mejoramiento y esplendor? ¿Qué otra cosa es en el día nuestra música teatral que un conjunto de insípidas e incoherentes imitaciones, sin originalidad, sin carácter, sin gusto y aplicadas casual y arbitrariamente a una necia e incoherente poesía? ¿Qué otra cosa nuestros bailes que una miserable imitación de las libres e indecentes danzas de la ínfima plebe? Otras naciones traen a danzar sobre las tablas los dioses y las ninfas; nosotros, los manolos y verduleras. Sin embargo, la música y la danza no sólo pueden formar el mejor ornamento de la escena, sino que son también su principal objeto, al fin, entre los concurrentes al teatro siempre habrá muchos de aquéllos que sólo tienen sentidos (ibídem, pág. 140).

También los Diarios contienen noticias musicales de valor. Antonio Gallego ha espigado en ellos datos que no concuerdan con la destemplada guitarra que Montesquieu nos adjudicara en sus Cartas persas y que, en general, beben en la idea platónica de que lo natural es superior a lo artificial, idea que en Rousseau se transforma en censura a la civilización y alabanza de lo «primitivo»e incontaminado. Abunda Jovellanos en esa valoración al tratar de nuevo el tema de las romerías — «el espectáculo de la inocencia pura y sencilla», «las únicas diversiones que conoce el pueblo de este país»— en la carta octava de las del Viaje de Asturias, conocidas vulgarmente como Cartas a Ponz ${ }^{47}$. La importancia etnográfica de este documento la demuestra la gran cantidad de comentarios que ha suscitado tanto dentro como fuera de Asturias, siendo el primer testimonio valioso que tenemos sobre la danza prima. Jovellanos no utiliza esta expresión - danza prima - ni aquí ni, según parece, en otros textos. En su carta a Carlos González de Posada, de 27 de octubre de 1792, habla de una «magnífica danza de hombres ${ }^{48}$ » que tampoco llama prima, término que, por el contrario,

${ }^{46}$ Antonio Gallego, La música en tiempos de Carlos III. Ensayo sobre el pensamiento musical ilustrado, Madrid, Alianza Editorial, 1988, pág. 96.

${ }^{47}$ Jovellanos, Cartas del Viaje de Asturias, vid. n. 45.

${ }^{48}$ En esta carta, Jovellanos se queja de la actuación de la justicia, que «con el temor de los palos, a que decía venir dispuestos los vecinos de los concejos inmediatos», disolvió la danza que había visto en 
sí emplea su amigo Francisco de Paula Caveda y Solares en la que éste envía a Jovellanos el 4 de julio de $1791^{49}$.

Cree Y. Cerra Bada que la distinción que Jovellanos realiza entre danzas de hombres y mujeres «tiene que ver con la moral de la época, que prohibía bailar juntas a personas de distinto sexo y portar palos u otras armas durante el baile»; sustentando su afirmación en: 1) Las Ordenanzas para el Gobierno de la Junta General de el Principado (1782), cuyo título V dice: «en las romerías especialmente han de asistir precisamente los jueces, quienes de ninguna manera permitirán que dancen hombres y mujeres juntos, que tengan palos aquéllos y vitoreen»; 2) Las Constituciones sinodales del Obispo González Pisador (1786), que prohibían «con pena de excomunión mayor, latae sententiae, las danzas, contradanzas y bayles de hombres y mugeres asidos de las manos, entrelazados y unidos entre sí; y 3) Un bando firmado por Carlos IV el 23 de junio de 1808,

\footnotetext{
Candás: «El día fue muy divertido, y lo hubiera sido mucho más si el juez, que no había leído mi Informe de espectáculos, no hubiese deshecho la más magnífica danza de hombres que había visto yo en mi vida. No pude dejar de manifestarle mi desaprobación; disculpóse con el temor de los palos, a que decía venir dispuestos los vecinos de los concejos inmediatos; yo le respondí que cuando la justicia era vigilante y humana, el pueblo era manso y tranquilo, y le dejé con la palabra en la boca», vid. Gaspar Melchor de Jovellanos, Obras completas, II. Correspondencia, $1^{\circ}$ (1767 - Junio de 1794), ed. José Miguel Caso González, Oviedo, Centro de Estudios del Siglo XVIII - Ayuntamiento de Gijón, 1985, vol. II, págs. 549-550.

49 «Así en los verbos majar, pisar, danzar, bien se pudieran indicar las costumbres y usos de mayar les árgomes; pisar el pan, el maíz, los chichos; danzar la danza prima, etc. Y aunque todo esto se pudiera expresar en los artículos árgoma, chichu, maíz, prima (danza), etc., como en estos sólo se define el nombre, y no lo que él representa, ni los usos que de él pueden venir, me parecía que se pudieran describir separadamente», vid. Jovellanos, Correspondencia, $1^{\circ}$ (1767 - Junio de 1794), vol. II, pág. 467. Caveda realiza estas observaciones a propósito del Diccionario asturiano que Jovellanos estaba proyectando. Cree José Miguel Caso González que «ésta es la primera vez que aparece en un texto escrito la expresión danza prima para designar a una de las más características de muchas, no todas, las comarcas asturianas», vid. JovelLanos, Correspondencia, $1^{\circ}$ (1767 - Junio de 1794), vol. II, pág. 472n. Debemos señalar, empero, que la expresión danza prima aparece ya en el fin de fiesta de don Ramón de la Cruz, Las provincias españolas unidas por el placer, cuando dice Pelayo «E si non fuera pur ell, / non viniera del cuncejo / de Llanes, yo, más pur ver / a nuestru príncipe nuebu, / que dicen que es guapetón, / que a danzar en sus festejus / la danza prima; y así / paz, y todu el mundo quietu», vid. Ramón de la Cruz, Sainetes, ed. Francisco Lafarga, Madrid, Ediciones Cátedra, 1990, pág. 450, v. 274. La pieza, que «cerró la función organizada por el Ayuntamiento de Madrid en el teatro del Príncipe el 29 de septiembre de 1789, para celebrar la coronación de Carlos IV y de María Luisa de Parma, así como la jura del Príncipe de Asturias», vid. Francisco Lafarga, «Introducción», en Cruz, Sainetes, págs. 9-53, págs. 50-51, constituye un bonito ejemplo de la «diversidad española» a que hace referencia la profesora Urzainqui en el espléndido trabajo que dedicó a este y otros «reflejos de esa realidad múltiple que entonces constituyen las Españas», vid. Inmaculada UnZainouu, «Visiones de Las Españas: Feijoo, Cadalso, Ramón de la Cruz y Salas», Dieciocho. Hispanic Enlightenment, 22.2, 1999, págs. 397-422, pág. 399. CERrA $\mathrm{B}_{\mathrm{ADA}}$, Bailes y danzas tradicionales, pág. 110n, da cuenta de la estampa, «Una gallega de Noya con un gallego de Tuy bailando la danza prima», en la obra de Juan de la Cruz Cano y Olmedilla, Colección de trajes de España, fechada en Madrid en 1777; y entre las principales canciones o bailes populares españoles registrados por José Subirá tanto en La tonadilla escénica, Madrid, Tipografía de Archivos, 1928-1930, 3 vols., vol. II, págs. 392 393, como en su Historia de la música teatral en España, Barcelona, Editorial Labor, 1945, págs 161-162, aparece la «danza prima (asturiana)», aunque no dice en qué pieza (vid. n. 107). Estoy convencido de que un estudio más profundo sobre el tema revelaría muchas más fuentes sin duda.
} 
que impedía «que en cualquier día o noche se junten en cuadrillas los asturianos $\mathrm{u}$ otras personas con palos o sin ellos [...] con el motivo de tener el baile de la danza prima ni otro alguno ${ }^{50}$. Por el contrario, J. M. Caso González opina que la separación de sexos es originaria y no producto del moralismo de la segunda mitad del siglo XVIII: «sin negar que esta presión haya podido existir, es posible que, sin embargo, la separación de sexos obedezca en algunos lugares a otras razones, y concretamente a la existencia primitiva de una danza masculina más o menos semejante, pero diferente. Y estas diferencias documentadas no tendrían fácil explicación si la separación de sexos no fuera originaria ${ }^{51}$ ». Ciertamente, el testimonio de Jovellanos parece claro:

Aunque las danzas de los hombres se parecen en la forma a la de las mujeres, hay entre unas y otras ciertas diferencias bien dignas de notarse. Seméjanse en unirse todos los danzantes en rueda, asidos de las manos, y girar en rededor con un movimiento lento y compasado, al son del canto, sin perder ni interrumpir jamás el sitio ni la forma. Son una especie de coreas a la manera de las danzas de los antiguos pueblos, que prueban tener su origen en los tiempos más remotos y anteriores a la invención de la gimnástica. Pero cada sexo tiene su poesía, su canto y sus movimientos peculiares, de que es preciso dar alguna razón.

Los hombres danzan al son de un romance de ocho sílabas, cantado por alguno de los mozos que más se señalan en la comarca por su clara voz y por su buena memoria; y a cada copla o cuarteto del romance responde todo el coro con una especie de estrambote, que consta de dos solos versos o media copla. Los romances suelen ser de guapos y valentones, pero los estrambotes contienen siempre alguna deprecación a la Virgen, a Santiago, San Pedro u otro santo famoso, cuyo nombre sea asonante con la media rima general del romance.

$[\ldots]$

Pero las danzas de las asturianas ofrecen ciertamente un objeto, si no más raro, a lo menos más agradable y menos fiero que las que acabamos de describir. Su poesía se reduce a un solo cuarteto o copla de ocho sílabas, alternado con un largo estrambote, o sea estribillo, en el mismo género de verso, que se repite a ciertas y determinadas pausas. Del primer verso de este estrambote que empieza: «Hay un galán de esta villa», vino el nombre con que se distinguen estas danzas.

$[\ldots]$

Los tonos son siempre tiernos y patéticos, y compuestos sobre la tercera menor. Llevan la voz de ordinario tres o cuatro mozas de las de más gallarda voz y figura,

\footnotetext{
${ }^{50}$ Cerra Bada, Bailes y danzas tradicionales, págs. 94-95.

${ }^{51}$ José Miguel Caso González, «Danza prima», en Gran Enciclopedia Asturiana, Gijón, [Silverio Cañada, Editor], 1970, vol. V, págs. 265-269, pág. 267.
} 
colocadas al frente del coro, y las otras van repitiendo ya la mitad de la copla, ya el estribillo, a cuyo compás giran todas sin interrupción sobre un mismo círculo, pero con lentos, uniformes y bien acordados pasos (Jovellanos, Cartas del Viaje de Asturias, vol. II, págs. 32-33, 35-36 y 39-40).

El resumen lo ha hecho el profesor Caso González: Jovellanos es el primero que se refiere al romance « ¡Ay!, un galán de esta villa ${ }^{52}$ », el primero que estudia y describe las danzas de asturianos y asturianas (y las letras que se utilizaba en ellas), y el primero que transcribe coplas de poesía tradicional al dictado de sus informantes, abriendo un camino que hoy es práctica obligada en nuestra ciencia: «¿Hay por ventura un medio más seguro de conocer bien los pueblos y provincias de un reino, que el de ir a los lugares mismos, y aplicar la observación a los objetos notables que se presentan?».

Jovellanos describe con minuciosidad «lo que el pueblo hacía al divertirse ${ }^{53}$ » y, en este sentido, su Carta octava — como también la novena, Sobre el origen y costumbres de los vaqueiros de alzada en Asturias - , constituyen, además de «dos preciosas joyas literarias, dos inestimables testimonios etnográficos y folklóricos ${ }^{54}$ ». Pero Jovellanos no fue ningún folklorista — como le llaman Navascués y otros—, sino un ilustrado que descubre al pueblo y que estudia sus costumbres «para hacerlo más feliz», como él mismo dice. «Hombre de principios sólidamente subordinados a un único fin: la reforma de la sociedad española ${ }^{55}$, en su trabajo, la barrera formada por la distancia social, que los recopiladores de otras épocas no se esforzaron por salvar, no se da, o mejor dicho, adquiere formas bien distintas a las de muchos ilustrados de su tiempo, para quienes los hechos que algunas veces relatan son, simplemente, «supersticiones», «errores» o «pecados». Jovellanos intenta comprender la diversidad cultural sin juzgarla de acuerdo con las pautas institucionales, y como la de Rousseau, la suya es una visión mítica de un mundo natural incontaminado que debe «servir de modelo a nuestra realidad corrompida ${ }^{56}$. Él mismo lo explica al comenzar la Carta novena a Ponz: «Mí método se ha reducido hasta aquí a observar cuanto puedo, según la rapidez de mis correrías, y a exponer a usted mi modo de pensar sin sujeción ni disimulo; y si alguna vez alabo o vitupero,

\footnotetext{
52 Ídem, «Ensayo de reconstrucción del romance “¡Ay un galán de esta villa!”», Archivum, IV, 1954, págs. 385-390.

${ }^{53}$ Gallego, La música en tiempos de Carlos III, pág. 123.

54 José Miguel Caso González, «Prólogo», en Jovellanos, Cartas del Viaje de Asturias, vol. I, págs. 1151, pág. 47.

55 Álvaro Ruz de la PeÑa, Introducción a la literatura asturiana, Oviedo, Biblioteca Popular Asturiana, 1981, pág. 140.

${ }^{56} \mathrm{M}^{\mathrm{a}}$ Dolores Juliano, Cultura popular, Barcelona, Anthropos Editorial del Hombre, 1986, pág. 10.
} 
es sólo cuando la vista del bien o el mal hacen que el corazón gobierne la pluma y le dicte sus sentimientos ${ }^{57}$ ».

\section{Benito Jerónimo Feijoo y Montenegro}

«Sé que entre los reprobadores de las romerías se encuentra el sabio Feijoo; pero ¿me atreveré a decir a usted lo que siento de su declamación? ¿Y por qué no? Léala, y si comparando su estilo pedantesco, su mala lógica y sus frívolos argumentos con sus otros escritos, no juzgase usted, como yo, que aquel discurso es un trozo de sermón trabajado en los primeros años, cuando no estaba aún ilustrada su razón crítica, ni formado su gusto, téngame usted por temerario ${ }^{58}$ ». Son palabras de Jovellanos a Ponz a propósito del discurso «Peregrinaciones sagradas y romerías», del Theatro crítico universal, o discursos varios de todo género de materias para desengaño de errores comunes, de Feijoo y Montenegro ${ }^{59}$ (1676-1764).

Aunque en sus obras demuestre ser un cualificado conocedor del pueblo y de sus condiciones de vida — que trata de entender, que no desprecia - las obras del Padre Feijoo están mucho más cargadas de «sermones y moralejas» que las de Jovellanos: «¿Qué son sino estiércol, inmundicia, abominación, eso que se llama solemnidad, fiesta, romería? ¿Qué son sino torpes cultos al ídolo de Venus, en vez de devotos obsequios a Dios y a sus Santos? ${ }^{60} »$. Combatir la superstición del pueblo, un «pueblo» al que trata de convencer y persuadir — «es ídolo del vulgo — dice- el error hereditario»— es el propósito del Padre Feijoo y el fin tanto de su Theatro crítico como de sus Cartas eruditas y curiosas.

A diferencia de Jovellanos, Feijoo no describe baile o danza alguna en su discurso; alude, sólo, a la "pasión desordenada de la tuna» al hablar de la primera de las especies — «las que se hacen a santuarios muy distantes»—; de la segunda — «las que llamamos romerías»— se limita meramente a condenarla:

Sábese de algunos extranjeros, que con el pretexto de ir o volver de Santiago se están dando vueltas por España casi toda la vida. Ví en esta ciudad de Oviedo un flamenquillo de catorce o quince años, natural de Lila, de admirable viveza de ingenio y bien cultado, pues era buen latino, mediano filósofo, hablaba razonablemente la lengua francesa y lo bastante para explicarse la italiana y la espanola. Decía éste que pasaba a Santiago con el motivo de voto que había hecho en

${ }^{57}$ Jovellanos, Cartas del Viaje de Asturias, vol. II, págs. 47-48.

58 Ibídem, pág. 43.

${ }^{59}$ Benito Jerónimo Feijoo y Montenegro, Obras escogidas. Teatro Crítico, ed. Agustín Millares Carlo, Madrid, Ediciones Atlas, 1961, tt. I (BAE LVI/I), IV (BAE CXLII/III) y VIII (BAE CXLIII/IV).

${ }^{60} \mathrm{Ibídem}$, t. IV (BAE CXLII/III), pág. 55. 
una grave enfermedad. Como me constase que era pobre, tanto movido de la piedad, como prendado de su espíritu, le ofrecí sustentarle y darle estudios en esta Universidad de Oviedo. Aceptó el muchacho para la vuelta de su peregrinación. Pero no volvió a Oviedo hasta ahora y dudo haya vuelto a su país. Por lo menos tres años después le he visto hecho vagabundo en otro lugar, donde él mismo, transitando yo por una calle, me conoció y llegó a hablarme. Hago memoria de este suceso, no por singular, sino porque me lo estampó más en la memoria el dolor de ver perdida una bella habilidad, por la pasión desordenada de la tuna. En lo demás puedo decir que he notado bastantes ejemplares de extranjeros, que con la capa de devotos peregrinos, son verdaderos tunantes, que de una parte a otra, sin salir de España y sin piedad alguna, se sustentan a cuenta de la piedad ajena (Feijoo y Montenegro, Teatro Crítico, vol. CXLII/III, págs. 53-54).

Por lo que respecta a la «producción musical» del polígrafo gallego, decir que ésta no se reduce a la «Música de los templos», discurso XIV del tomo primero del Theatro crítico; son más los textos de esa colección —o de las Cartas — dedicados a este arte — el preferido del benedictino_-, así como incontables las alusiones musicales que se deslizan a lo largo de su extensa producción «y que nos prueban, una vez más, la gran pasión y conocimiento que del arte de los sonidos poseía el sabio orensano ${ }^{61}{ }^{»}$. Pero Feijoo se interesó más por la música erudita que por la popular. Sus textos son imprescindibles para el conocimiento de las ideologías musicales del tiempo, pero aportan poco, o de forma muy indirecta, al estudio de la música popular del período, que queda reducida a una leve pintura de los que gustan de «minuetes», «recigados», «arias», «alegros», «gigas», «saraos» y otras «música de la tararira», por ejemplo, o a tratar de la moralidad e inmoralidad de los bailes de moda.

La «unilateralidad» de los juicios realizados por los estudiosos sobre el pensamiento musical de Feijoo procede, ciertamente, del examen exclusivo de la «Música de los templos»; un discurso que, como el que dedica a las romerías, pertenece a los primeros años del maestro. "Ni hice ni pude hacer observación alguna sobre esta materia», confiesa el fraile, que vuelve a reconocer su inexperiencia a la altura del discurso XI del tomo VIII de su Theatro: «Importancia de la ciencia física para la moral»: «Yo — dice— nunca vi baile alguno de estos que llaman de moda, pero por la relación de muchas personas que asistieron a ellos hago juicio de que todos o casi todos los que se practican en España entre caballeros y señoras nada tienen de indecentes. [...] Los movimientos que cons-

${ }^{61}$ Antonio Martín Moreno, El Padre Feijoo y las ideologías musicales del XVIII en España, Orense, Instituto de Estudios Orensanos 〈Padre Feijoo〉, 1976, pág. 67. 
tituyen el baile, considerados por sí solos en cuanto naturales, pertenecen al físico, en cuanto artificiosos, al profesor del arte de danzar». "Ilustrada ya su razón crítica», Feijoo — que vuelve a hablar de oídas — se nos presenta aquí como un «moderno», un «moderado de la verdad, de los pocos, por cierto, con que cuenta la historia de la literatura española ${ }^{62} »$ :

Teniendo escrito todo lo que queda arriba en asunto de los bailes, recibí carta de un íntimo amigo mío, el cual me aseguraba tener noticias ciertas de que los bailes, como comúnmente se practica, aun dentro de España, son muy perniciosos, y que yo no debía hacer concepto de los que hay en otras partes, por los de Oviedo, que acaso serán muy distintos. Convengo en que será así, pues me lo hace creer el juicio y veracidad del sujeto que me lo ha asegurado, y también convengo en que, siendo común el daño, debe ser común el remedio: prohibiendo los bailes los que tienen autoridad para ello, y declamando rigurosamente contra ellos los que ejercen el ministerio del púlpito. Mas esto en ninguna manera infiere que todo baile sea gravemente pecaminoso. Esta es una de las muchas cosas que el modo y las circunstancias constituyen lícitas o ilícitas (ibídem, vol. CXLIII/IV, pág. 154).

\section{Girolamo Giacomo Casanova}

La literatura del xVIII — y la del xIx, y la del xx — está plagada de alusiones a la moralidad del baile, a su conveniencia e inconveniencia, a la bondad y maldad de su práctica, a la tipificación de algunos de ellos como singularmente perversos ${ }^{63}$. Uno de los testimonios más célebres del siglo es, sin duda, el de Giacomo Casanova (1725-1798), quien en su particular autobiografía utiliza las más

\footnotetext{
${ }^{62}$ Carmen Martín Gaite, «Prólogo», en Benito Jerónimo Fejoo y Montenegro, Teatro crítico universal. Cartas eruditas y curiosas. (Antología), Madrid, Alianza Editorial, 1970, págs. 7-25, pág. 24.

63 «Algunos teólogos austerísimos del siglo xviII llevaron su rigorismo hasta condenar todo género de danzas, incluso las tenidas por más honestas y recatadas, tachando de laxo al P. Feijóo, que, como moralista más práctico, las consideraban lícitas en algunos casos. Vide, por ejemplo: Bayles mal defendidos y Señeri, sin razón impugnado por el Rmo. P. Feijó, su autor D. Nicasio de Zárate, Presbítero y Missionero en el Obispado de Jaén. Madrid, imp. de Manuel Fernández». Continúa Menéndez Pelayo su discurso dando fe del edicto del Inquisidor general don Francisco Pérez de Prado y Cuesta, Obispo de Teruel, por el que prohibe «severamente los bailes provocantes y lascivos conocidos con el nombre de "el amor, la cadena, el órgano, el chulillo, el sueño, la sombra, el coco, el zurruqui, etc.", etcétera, cuyos solos nombres indican ya que debían de ser una transformación muy cínica y desvergonzada, de aquella antigua zarabanda que el P. Mariana execró, llamándola "baile y cantar tan lascivo en las palabras, tan feo en los meneos, que basta para pegar fuego a las personas más honestas" ", vid. Marcelino Menéndez Pelayo, Edición nacional de las obras completas de..., III. Siglo XVIII, dir. Miguel Artigas Ferrando. Historia de las ideas estéticas en España, ed. Enrique Sánchez Reyes, Santander, Aldus, S.A. de Artes Gráficas, mcmXLvII, págs. 656-657.
} 
vívidas expresiones para la descripción del fandango, que tuvo ocasión de presenciar en Madrid, en $1767^{64}$ :

El gran espectáculo que me entusiasmó tuvo lugar al final del baile, cuando al son de una orquesta, después de un aplauso general, empezó el baile de parejas más loco e interesante que había visto en mi vida. Era el fandango, del que creía tener una idea exacta, aunque estaba muy equivocado. No lo había visto bailar más que en Italia y en Francia, en el teatro, donde los bailarines no hacían el menor de los gestos que hacen a esta danza verdaderamente seductora. No sabría describirla. Cada uno con su cada una. Danzaban frente a frente, no dando nunca más de tres pasos, tocando unas castañuelas que se sujetan con los dedos y acompañando la armonía con tales actitudes que sería imposible verlas más lascivas. Las del hombre indicaban claramente el acto del amor consumado, las de la mujer, el consentimiento, el arrebato, el éxtasis del placer. Me parecía que ninguna mujer podía negar nada a un hombre con el que hubiera bailado el fandango. El placer que me producía verlo me arrancaba gritos; la máscara que me había llevado allí me dijo que para tener verdadera idea de esta danza había que verla ejecutada por gitanas con un hombre que la bailase tan perfectamente como ellas. Pregunté si la Inquisición no encontraba nada que objetar contra esta danza que inflamaba el alma, y me respondieron que estaba totalmente prohibida y que no se habrían atrevido a bailarla si el conde de Aranda no hubiera dado permiso. Me dijeron que cuando le daba por no concederlo todo el mundo se iba del baile descontento, pero que se iban elogiándole cuando la permitía (Casanova, Memorias de España, págs. 29-30).

En el Diccionario de autoridades (1726-1737) se dice que el fandango es un «baile introducido por los que han estado en los Reinos de las Indias ${ }^{65}$ », hecho que Cotarelo y Mori fija «á fines del siglo XVII», porque, dice, «no se le menciona en los entremeses ni bailes anteriores ${ }^{66} »$.

El primer texto escrito en que figura el término fandango parece que es $E l$ novio de la aldeana (1705), entremés en donde "se "canta y toca el fandango" con unas coplas que principian: "Asómate á esa ventana,/cara de borrica flaca;/á la ventana te asoma/cara de mulita roma". "Deja de cantar y tocando arman los dos la gritería, chillidos y otras cosas que se usan cuando se cantan los fandangos

${ }^{64}$ Giacomo Casanova, Memorias de España, ed. Ángel Crespo, Barcelona, Editorial Planeta, 1986.

${ }^{65}$ Y termina: «que se hace al són de un tañido mui alegre y festivo», vid. Diccionario de autoridades, Madrid, Imprenta de Francisco del Hierro, 1726-1737, 3 vols. [reed. facs. Madrid, Editorial Gredos, 1969], pág. 719. El segundo volumen de este diccionario, en el que aparece la mencionada voz, se publicó en 1732.

${ }^{66}$ Cotarelo y Mori, Colección de entremeses, vol. I, pág. ccxlv. 
en bulla, etc." Cantan de nuevo, y "Vuelven á hacer ahora los dos la misma demostración antecedente, acostumbrada en los fandangos" ${ }^{\prime 7}$. Dice este autor en el mismo sitio que en la mojiganga de Los Sopones (1723), de Cañizares, se baila con el estribillo: «Me dice del fandanguillo,/¡ay, picarí picarillo!/Mil finecitas al son», y que desde entonces fue «comunísimo en España, sobre todo en Andalucía». Señalar, por último, que en el célebre Viaje por España, de Doré y Davillier, se halla una descripción del fandango que de ser cierta estaríamos ante, quizá, la primera pintura literaria del baile: «un sacerdote español llamado Martí, que era deán del capítulo de Alicante, escribía desde Cádiz, el 16 de las calendas de febrero de 1712, una carta en latín en la que daba la descripción del fandango ${ }^{68} \gg$.

En su trabajo sobre los bailes de candil andaluces, Miguel Ángel Berlanga hace hincapié en la segunda acepción que el Diccionario de autoridades da a la voz fandango: «qualquiera funcion de banquéte, festéjo ù holgúra à que concurren muchas personas ${ }^{69} »$, para concluir que nunca se identificó con tal o cual baile o danza concretos: "ya desde antiguo, los fandangos significaban fiesta, y esa fiesta se hacía — y se sigue haciendo — con músicas tradicionales de diversa índole ${ }^{70} \gg$. Sustenta su argumentación en muchos y variados textos que confirman la opinión de Cotarelo - y en parte también la suya — y que van desde el célebre sainete de don Ramón de la Cruz El fandango de candil, obra que «se estrenó el 11 de julio de 1768 en el teatro del Príncipe ${ }^{71_{1}}$, hasta la definición que Marcos A. Morínigo dio de la voz argentina fandango en su célebre Diccionario de americanismos: «Baile en casa pobre ${ }^{72}$, entre otros.

También se interesaron por el fandango muchos ingleses que, como Casanova, retrataron en sus memorias la impresión que les causó el baile más célebre de cuantos tuvieron ocasión de contemplar en sus viajes por España. Desde Los curiosos impertinentes, de Robertson ${ }^{73}$, son ya unas cuantas las obras y los

${ }^{67}$ Ibidem.

68 «Ya conocéis —dice el deán Martí— esta danza de Cádiz, famosa desde hace tantos siglos por sus pasos voluptuosos que se ven ejecutar todavía en los arrabales y en todas las casas de esta ciudad ante los increíbles aplausos de los espectadores. No solamente le honran las negras y las personas de baja condición, sino también las mujeres más nobles y de encumbrado nacimiento...», vid. Doré y Daviluer, Viaje por España, pág. 504.

69 También se dice que «fandanguero» es el «aficionado à bailar el fandango, ù à assistir à convites ò festejos», dando como ejemplo la «Com. Amor es todo invencion. Sainet. I. Fandanguéro empieza tu. / Qué es esso de fandanguéro / estando en el mundo yo?», vid. Diccionario de autoridades, ibídem.

${ }^{70}$ Miguel Ángel Berlanga Fernández, Bailes de candil andaluces y fiesta de verdiales. Otra visión de los fandangos, Málaga, Servicio de Publicaciones del Centro de Ediciones de la Diputación Provincial, 2000, pág. 22.

${ }^{71}$ Lafarga, «Introducción», en Cruz, Sainetes, pág. 36.

72 Y también «Bochinche, riña, desorden: Se armó un fandango», vid. Marcos A. Morínıgo, Diccionario de americanismos, Barcelona, Muchnik Editores, 1985, pág. 261.

${ }^{73}$ Ian RoвеRтsоn, Los curiosos impertinentes. Viajeros ingleses por España, 1760-1855, pról. Manuel Fraga Iribarne, Madrid, Editora Nacional, 1975. 
autores que se han acercado a la mirada de estos «trotamundos», destacando, entre otros, los trabajos de Blanca Krauel Heredia ${ }^{74}$, Ana Clara Guerrero ${ }^{75}$ y, por lo que nos atañe, el de Judith Etzion ${ }^{76}$. Coinciden todos en subrayar la importancia que los viajeros concedían al baile en el conjunto de las costumbres y diversiones de los españoles, $y$, singularmente, la afición al mismo por parte del sexo femenino: "“ninguna mujer española puede resistir el deseo que siente de unirse a la danza cuando se oye cualquier instrumento musical", hasta el punto de que "las más venerables matronas no se consideran jamás excluidas de esta diversión por su edad"77». De los dos bailes que distingue el reverendo Clark, la sequedilla y el fundungo, es este último el más comentado, y vapuleado, por los turistas dado su carácter «lascivo» e «indecente», pasando las seguidillas manchegas casi inadvertidas a los ojos de aquéllos. Pareciéndoles indigno de la vieja Europa, buscan para el fandango los más curiosos orígenes: «Si para Townsend nació entre los "moros", Twiss se inclina por "los indios", Dalrymple apunta hacia las Indias occidentales, a donde habría llegado desde el golfo de Guinea, Swinburne señala a los negros de La Habana como sus inventores, y el reverendo Clarke, evidentemente un poco desorientado, se remonta a los romanos, aunque reconoce algunas influencias morunas. En cualquier caso y sea cual sea su lugar de procedencia, el fandango a los ojos de los viajeros está sólidamente establecido en la Península y es ya tan español que "todos nacen con él en la cabeza y en las piernas"78».

\footnotetext{
${ }^{74}$ Blanca Krauel Heredia, Viajeros británicos en Andalucía. De Christopher Hervey a Richard Ford (17601845), Málaga, Secretariado de Publicaciones de la Universidad de Málaga, 1986; e ídem, Viajeros británicos en Málaga (1760-1855), Málaga, Servicio de Publicaciones de la Diputación Provincial de Málaga, 1988.

${ }^{75}$ Ana Clara Guerrero, Viajeros británicos en la España del siglo XVIII, Madrid, Aguilar, S.A. de Ediciones, 1990.

${ }^{76}$ Judith Etzion, «The spanish fandango - from eighteenth-century "lasciviousness" to nineteenthcentury exoticism», Anuario Musical, 48, 1993, págs. 229-250.

${ }^{77}$ Guerrero, Viajeros británicos en la España del siglo XVIII, pág. 405. La primera de las citas es de Richard Croкer, Travels through several provinces of Spain and Portugal, by... Captain in the late $99^{\text {th }}$ Regiment of Foot, London, J. Robson, T. Payne, Mrs. Codell and Davis, 1979, pág. 149; y la segunda de Edward CLARKe, Letters concerning the Spanish nation: written at Madrid during the years 1760 and 1761, London, Becket and P. A. de Hondt, 1763, pág. 341.

${ }^{78}$ Ibídem, pág. 407. Joseph Townsend, A journey through Spain in the years 1786 and 1787; with particular attention to the agriculture, manufactures, commerce, population, taxes and revenue of that country,

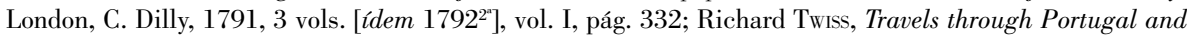
Spain in 1772 and 1773, by..., London, G. Robinson, T. Becket and J. Robson, 1775, pág. 156; William Dalrymple, Travels through Spain and Portugal in 1774; with a short account of the spanish expedition against Algiers in 1775, by Major..., London, J. Almon, 1777, pág. 51; Henry Swinburne, Travels through Spain in the years 1775 and 1776 in which several monuments of Roman and Moorish Architecture are illustrated by accurate drawing taken in the spot, by..., London, P. Elmsby, 1779 [ídem 17872"], pág. 228; CLaRKE, Letters concerning the Spanish nation, pág. 341; Swinburne, Travels through Spain in the years 1775 and 1776, pág. 228.
} 
Que el fandango gustaba a todos era un hecho del que dieron testimonio tanto la prensa de costumbres de la época, que ve en éste el baile nacional, como los turistas, quienes, como Twiss, hablan de dos clases de fandango: la «decente» y «la otra»; siendo esta última, lógicamente, «la más peligrosa», la que, como a Casanova, más interesó a los viajeros. Quizá fuera la primera, «la autorizada», la bailada «con modestia», la que Casanova había presenciado «en Italia y en Francia, en el teatro, donde los bailarines no hacían el menor de los gestos que hacen a esta danza verdaderamente seductora», de ahí su interés por la segunda. Es un interés que comparte con otro italiano, Giuseppe Baretti, quien cincuenta y dos años antes de que Friedrich Arnold Brockhaus comenzara a publicar en doce tomos la adaptación y traducción al alemán de la Histoire de ma vie jusqu'à l'an $1797^{79}$, del célebre libertino, había dado a la estampa londinense la crónica de un viaje por España ${ }^{80}$ en la que certificaba que este país «rebosa de improvisados cantores, o poetas, o lo que quiera llamárseles ${ }^{81}$ », diciendo a continuación del fandango que «en los territorios papales este tipo de diversiones están prohibidas ${ }^{82}{ }_{»}$. «iNinguna mirada modesta podría contemplar sin sonrojarse esos ademanes, esas contorsiones del cuerpo y posturas de las piernas! Una buena bailadora de fandango debe permanecer cinco minutos en el mismo lugar, retorciéndose como un gusano al que se ha partido en $\operatorname{dos}^{83}$ ».

Convertido en algo más exótico que impúdico, el siglo Xix contempla el ocaso del fandango, que todavía continúa agradando a los extranjeros. En el libro del viaje por España que en 1862 hicieron Gustave Doré y Charles Davillier leemos: «Después de treinta o cuarenta años el fandango ha sido un poco abandonado. No había antiguamente una sola provincia de España en la que no se conociera perfectamente esta danza ${ }^{84}{ }$. Quizá este fuera el motivo por el que la acepción «reunión festiva y bulliciosa acompañada de bailes a la luz de uno o dos can-

\footnotetext{
${ }^{79}$ Vid. Ángel Crespo, «Introducción», en Casanova, Memorias de España, págs. IX-LVI.

${ }^{80}$ Giuseppe Baretti, A journey from London to Genoa through England, Portugal, Spain and France, London, T. Davies and L. Davies, 1770, 4 vols.

81 «Poco más allá de Talavera dejaron el camino y torcieron hacia Toledo, siguiendo el que les indicó un muchacho cantor de coplas, lo que vino a confirmar la creencia de Baretti de que el país rebosa de improvisados cantores...", op. cit. por Robertson, Los curiosos impertinentes, pág. 62. Y en otro sitio: "Muchos atardeceres, yendo de camino, se entretuvo en contemplar las danzas de los aldeanos, pues casi todas las posadas tenían a un hombre con su guitarra; de no ser así, "puede obtenerse uno por cuatro cuartos, con lo que se reúne a todos los hombres y mujeres jóvenes de la vecindad y se pasa una hora en agradable compañía"», ibídem, págs. 63-66.

${ }^{82}$ Guerrero, Viajeros británicos en la España del siglo XVIII, pág. 406.

${ }^{83}$ Swinburne, Travels through Spain in the years 1775 and 1776, pág. 46, op. cit. por Guerrero, Viajeros británicos en la España del siglo XVIII, pág. 405.

${ }^{84}$ Doré y DaviLlier, Viaje por España, págs. 480-481.
} 
diles» de la palabra fandango iba a crecer en importancia, siendo uno de los significados de la voz que leemos en el Diccionario de música de Fernando Palatín (Sevilla, 1818): «Lo mismo que Baile de botón ó cascabel gordo ${ }^{85}$ ».

\section{Antonio Valladares de Sotomayor y Juan Antonio de Iza Zamácola y de Ozerín, «Don Preciso»}

Pero no es cuestión de seguir hablando del fandango, ni de esta sólida pareja -baile y moralidad - que tantos ríos de tinta ha hecho correr a través de los siglos. A penas queda espacio para referir — referir sólo— los nombres de algunas colecciones de seguidillas que se cuentan entre las primeras recopilaciones folkloricas de nuestro país — al margen, el intento frustrado de José González Torres de Navas «de presentar una recopilación de música característica española formando una colección de aquellas canciones que se pudieran recoger de viva voz y declarando la demarcación donde se las cantaba», de que nos habla Subirá en su Historia de la música española e hispanoamericana ${ }^{86}$ - Me estoy refiriendo a la Colección de seguidillas o cantares, del periodista y dramaturgo Antonio Valladares de Sotomayor ${ }^{87}$ (1740-1820?), y a la más conocida Colección de las mejores coplas de seguidillas, tiranas y polos, que se han compuesto para cantar a la guitarra, de Juan Antonio de Iza Zamácola y de Ozerín, «Don

\footnotetext{
${ }^{85}$ Fernando Palatín, Diccionario de música. (Sevilla, 1818), ed. Ángel Medina, Oviedo, Servicio de Publicaciones de la Universidad, 1990, pág. 63. Así es como explica Ch. Davillier estos bailes: «Se llama en Andalucía "bailes de candil" a los bailes de la gente del pueblo. Tienen lugar ordinariamente en la taberna o botillería o en alguna casa de aspecto modesto. Se ha llamado así a estas reuniones a causa de su pobre alumbrado, que consiste casi siempre en un candil, lamparilla de cobre o de hierro que se usa mucho en Andalucía y en otras partes de España. [...] También se ha dado a estos bailes otro nombre bastante pintoresco, y es el de bailes de botón gordo o de cascabel gordo. Con él se alude a los botones de filigrana de plata que adornan comúnmente las chaquetillas y pantalones de la gente del pueblo», vid. Doré y DAvILLIER, Viaje por España, págs. 488-489.

${ }^{86}$ Subirá, Historia de la música española, pág. 887: «El 14 de marzo de 1799 se realizó el primer intento, frustrado como era natural, de presentar una recopilación de música característica española formando una colección de aquellas canciones que se pudieran recoger de viva voz y declarando la demarcación donde se las cantaba. En efecto, el hoy desconocido folklorista José González Torres de Navas solicitó en una memoria la protección oficial, sin que se atendiera tal propósito. El documento se hallaba en los archivos de Alcalá». De haberse llevado a cabo el proyecto, «el nombre de España se hubiera colocado entre los primeros lugares en la investigación etnomusicológica universal», vid. Josep Crivillé i Bargalló, «La etnomusicología: sus criterios e investigaciones. Necesidad de esta disciplina en el tratamiento de toda música de tradición oral», en Actas del I Congreso Nacional de Musicología. (Sociedad Española de Musicología), Zaragoza, Institución ‘Fernando El Católico〉 (C.S.I.C.) de la Excma. Diputación Provincial de Zaragoza, 1981, págs. 143-166, pág. 150, pero no fue así. (La obra del Padre Amiot, Mémoire sur la musique des Chinois tant anciennes que modernes, está fechada en París en 1776).

${ }^{87}$ Antonio Valladares de Sotomayor, Colección de seguidillas ó cantares, Madrid, Imprenta de Franganillo, 1799, en José María Sвавві, El refranero general español, parte recopilado, y parte compuesto, por..., Madrid, Imprenta de A. Gómez Fuentenebro, mbcccLxxv, vol. IV.
} 
Preciso $^{88}>$ (1756-1826), ambas de $1799^{89}$. De las dos da cuenta la Noticia histórica, de Guichot y Sierra ${ }^{90}$, siendo para nosotros más importante la segunda que la primera.

Antes que don Alejandro, de ‘Don Preciso〉 se habían ocupado, entre otros, Sbarbi $^{91}$, Barbieri ${ }^{92}$, Rodríguez Marín ${ }^{93}$, Palau ${ }^{94}$ y Cejador ${ }^{95}$; después de él Hergueta Marín ${ }^{96}$, Cossío ${ }^{97}$, Menéndez Pelayo ${ }^{98}$ y Martín Gaite ${ }^{99}$, y entre los musicólogos, José Subirá ${ }^{100}$ y, sobre todo, $\mathrm{M}^{\mathrm{a}}$ Carmen García-Matos Alonso ${ }^{101}$.

\footnotetext{
88 Juan Antonio de Iza Zamácola y de Ozerín, «Don Preciso`, Colección de las mejores coplas de seguidillas, tiranas y polos que se han compuesto para cantar a la guitarra, Madrid, Imp. de Repullés, 1816, 2 vols. Dice Cossío en su biografía de Don Preciso que éste murió en Madrid, el 24 de marzo de 1826, a los sesenta y nueve años de edad, vid. José María de Cossío, «Una biografía de Don Preciso», Revista de Bibliografía Nacional, V, 1944, pág. 396; por el contrario, García-Matos Alonso afirma que debió fallecer hacia 1818 ó 1819 , y que en 1820 ya no vivía, pues de lo contrario se hubiera repatriado a España como consecuencia de los acontecimientos políticos, vid. M ${ }^{\mathrm{a}}$ Carmen García-Matos Alonso, «Un folklorista del siglo xviII: ‘Don Preciso»», Revista de Musicología, IV, 1981/2, págs. 295-307, pág. 298.

${ }^{89}$ El título completo de la primera es Colección de seguidillas ó cantares, de los más instructivos y selectos. Enriquecida con notas y refranes en cada uno, para hacer más fácil su inteligencia, y la lección más fértil y agradable. Se ilustra con Anécdotas, Apólogos, Cuentos y Sentencias morales, políticas y jocosas. Todo recogido, dispuesto y exornado, para acreditar que ninguna nación tiene un ramo de literatura tan exquisito y lacónico, tan abundante de conceptos sublimes, de elegantes máximas, y de morales sentencias en la Poesía, como el que componen nuestras seguidillas. Por D.A.V.D.S.

Consta la obra de doscientas seguidillas, a las que SBARBi, El refranero general español, añadió las «Coplas que concluyen en juegos de palabras y Refranes castellanos», que se hallan al final del tomo primero de la Colección de Don Preciso. Pero el «plan» de Valladares, a diferencia del de este último, es «todo original, seguidillas y notas», es decir, se trata de una obra de creación (como él mismo dice):

Siendo esto constante, y que nuestra Nación inventó las seguidillas (no sabemos ni cuándo, ni quién), que es la que únicamente está en posesión de su composición y uso, y que son infinitas las que posee [...], teniendo la gran recomendación de que nacieron en España, que en ella sólo se usan, y que ninguna nación ha sabido imitarlas, por más que todas compitan en aplaudirlas.

Estas razones me hicieron creer que sería bien recibida del público una colección de las más selectas, sin más trabajo que el que emplease en recogerlas [...]. Pero considerando después que para presentar al público su belleza, necesitaba de cierto adorno que yo no era capaz de producir [...] me atreví a formar un plan $[\ldots]$ y tuve por conveniente que fuese este tomo todo original, seguidillas y notas; porque no recibiéndole bien el público, sólo yo sufriría la pena, en justo castigo del atrevimiento.

${ }^{90}$ Guichot y Sierra, Noticia histórica del folklore, pág. 140.

${ }^{91}$ SваRвi, El refranero general español, pág. 237.

${ }^{92}$ Francisco Asenjo Barbieri, Las castañuelas. Estudio jocoso dedicado a todos los boleros y danzantes, por uno de tantos... Madrid, Imp. de José M. Ducázcal, 1879 [reprod. facs. Madrid, Ediciones Turner, 1981], págs. 34 y 36 .

${ }^{93}$ Francisco Rodríguez Marín, Cantos populares españoles, rec., ord. e ilus. por..., Sevilla, Francisco Álvarez y Cía., 1882-1883, 5 vols. [reed. Buenos Aires, Bajel, 1949 (1 vol.) y Madrid, Atlas, 1951], vol. V, pág. 150.

${ }^{94}$ Melchor de Palau, Cantos populares y literarios, rec. por..., Barcelona, Montaner y Simón, 1900, pág. 14.

${ }^{95}$ Julio Cejador y Frauca, Historia de la lengua y literatura castellana, Madrid, Tip. de la Revista de Archivos, 1915-1922, 14 vols. [1932 $3^{3}$; reprod. facs. Madrid, Editorial Gredos, 1972], vol. VI, págs. 292 y 378.

${ }^{96}$ M. Hergueta Marín, Don Preciso, su vida y su obra, Madrid, Tipografía de la Revista de Archivos, 1930.

${ }^{97}$ Cossío, «Una biografía de Don Preciso», vid. n. 88.
} 
El deseo de restablecer en España la «música nacional» y el divulgar «las coplas que comúnmente cantamos en España» son los motivos que aduce este «folklorista» del siglo xvIII para justificar el por qué de la colección que publica; motivos que tienen que ver con los que tiempo atrás habían movido al Padre Feijoo a escribir la «Música de los templos» (1726) y al Marqués de Ureña sus Reflexiones sobre la arquitectura, ornato y música del templo (1785), y que supusieron el «surgimiento de los ideales del Nacionalismo musical español ${ }^{102} »$.

Al margen de ello —o precisamente por ello— la Colección de «Don Preciso» posee cierta importancia como ejemplo de «folklore» avant la lettre. En las introducciones a los dos volúmenes de que consta la obra — que «gozaron de tan favorable acogida que llegaron a realizarse hasta seis ediciones ${ }^{103}{ }$ el autor da muestras de una voluntad investigadora próxima a la de los folkloristas decimonónicos, dejando claro que recogiendo y dando a la prensa dichos cantares hace «un servicio a la patria», porque destierra con ellos «los indecentes y escandalosos que sólo circulan ${ }^{104}$ » y evita que desaparezcan - $-\mathrm{y}$ «a los españoles venideros les quede, a lo menos, alguna noticia de las costumbres de este siglo y de sus bailes nacionales ${ }^{105_{\Downarrow}}$ -

Refugio de músicas populares del más diverso signo fue la tonadilla escénica: «grito de protesta, grito de indigenismo simpático contra el extranjerismo de la ópera, contra el afrancesamiento de la literatura... y contra el italianismo

\footnotetext{
${ }^{98}$ Menéndez Pelayo, Historia de las ideas estéticas en España, vol. III, págs. 657-659.

${ }^{99}$ Carmen Martín Gaite, Usos amorosos del dieciocho en España, Barcelona, Editorial Anagrama, 1987,
} pág. 65.

100 SuBIRÁ, Historia de la música española, págs. 507 y 620.

${ }^{101}$ García-Matos Alonso, «Un folklorista del siglo xviII: 〈Don Preciso»», vid. n. 88.

102 García-Matos Alonso reproduce en su trabajo diversos fragmentos de las introducciones a los dos volúmenes de la Colección de Don Preciso que, como el siguiente (Iza Zamácola y de Ozerín, Colección de las mejores coplas de seguidillas, vol. I, pág. XLI) prueban esta afirmación:

El deseo, pues, de restablecer en España la «música nacional» y apartar cuanto sea posible de nuestras vidas la italiana que no puede producir otro efecto que el de debilitar y afeminar nuestro carácter, y por otra parte, las instancias que me han hecho algunos amigos para que publique esta colección de las coplas que comúnmente cantamos en España, porque en ellas brilla el ingenio, agudeza y chiste propios de nuestra nación, me han hecho creer que podrá ser bien recibida del público esta obrita.

Azote de afrancesados, «currutacos», «pirracas» y «madamitas de nuevo cuño», el «fanatismo hispanófilo» de Don Preciso (Menéndez Pelayo, Historia de las ideas estéticas en España, vol. III, pág. 657) parió otros muchos textos de similar carácter, como El libro de moda en la feria o Elementos de la ciencia contradanzaria, vid. García-Matos Alonso, «Un folklorista del siglo xviII: «Don Preciso»», pág. 297; Francisco José León Tello, La teoría española de la música en los siglos xVII y XVIII, Madrid, C.S.I.C., 1974, pág. 401; Martín Moreno, El Padre Feijoo, págs. 335-336, y Gonzalo Martín Tenllado, Eduardo Ocón. El Nacionalismo musical, Málaga, Ediciones Seyer, 1991, págs. 147-151.

${ }^{103}$ García-Matos Alonso, «Un folklorista del siglo xviII: 〈Don Preciso»», pág. 299.

${ }^{104}$ Iza Zamácola y de Ozerín, Colección de las mejores coplas de seguidillas, vol. I, pág. xxII.

${ }^{105}$ Ibídem, pág. XII. 
de la música», $(\text { Pedrell })^{106}$. En el espléndido estudio sobre esta «obra del pueblo y para el pueblo» que publicó Subirá al concluir la tercera década del siglo pasado, se mencionan hasta treinta y siete canciones o bailes populares españoles, de los que si algunos «se dan por unidades, otros en cambio, se cuentan por docenas, o cuando menos con acentuada profusión ${ }^{107}{ }_{»}$. Era esta una manera de acuñar «los atributos nacionales» en la literatura musical tonadillesca, a la que habría que añadir el carácter melódico o rítmico «que delata una filiación folklórica indiscutible», los sonadores utilizados para acompañar las melodías «(guitarra o los instrumentos de arco que se debían tocar 〈rasgueados〉, ‘punteados> o — según también se declara muy frecuentemente- <como guitarras)», y los números no escritos «que se introducían tomándolos del repertorio calle-

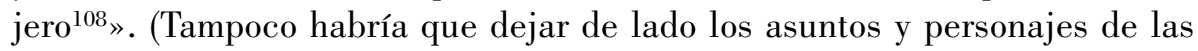
tonadillas, colmados de tipos y costumbres de lo más variopinto) ${ }^{109}$.

\section{Don Ramón de la Cruz}

Al margen de su intrínseco valor musical —y teatral—, sainetes, entremeses, comedias, zarzuelas, óperas, loas, fines de fiesta y tonadillas constitupág. 77.

${ }^{106}$ Cit. por José Subirá, La tonadilla escénica. Sus obras y sus autores, Barcelona, Editorial Labor, 1933,

${ }^{107}$ SubiRÁ, La tonadilla escénica, vol. II, págs. 392-393. La «lista» de las principales canciones o bailes populares españoles registrados por este autor tanto en la mencionada obra como en su Historia de la música teatral en España, págs. 161-162, es la siguiente: Alcarria (canción de la); Alemanda; Andaluza (canción); Asturiana (canción); Bailes sin denominación expresa; Baile americano, indio, inglés, moro, vizcaíno, de enanillos en la procesión del Corpus, etc.; Bailetes; Balear (canción); Boleras; Boleras murcianas y de diversas regiones hispánicas; Buenos Aires (canción de); Caballo; Cachirulo (canción del); Canciones de ciego; Canciones de cuna; Catalana (canción); Con el dingo; Chamberga; Contradanzas; Cumbés; Danza prima (asturiana); Dulzaina; Fandangos; Folías; Francesas (canciones); Gaitas, gaitillas y gallegadas; Gitanas (canciones); Gritos de vendedores; Guacharita (baile); Guajiras; Jácaras; Jopeos; Jotas (la más antigua data de 1758 y es de Misón); Malagueñas; Matarile (canción de); Manguindois (baile de); Mayo (canciones de); Mora (canción); Muñeira; Murciana (canción); Nanas o canciones de cuna; Padedú (baile); Pasiega (canción); Pastoral (pastorelas); Payos (canciones de); Pelindanguilla (baile); Polacas; Polos; Romances populares; Seguidillas (aminuetadas, boleras, de ciegos, garruchonas, gitanas, majas, manchegas, murcianas, serias, etc.); Suiza (canción); Taconeo; Tiranas; Tononés; Tuna (canción de); Vascas (canciones); Villancicos; Zarabanda; Zarembeque y Zorongo. J. Subirá dedicó un apunte al tema de la música popular en este género en el artículo, «El folklore musical en la tonadilla escénica y nuestro ambiente musical de aquel tiempo», Segismundo, VIII, 1965, págs. 1-2.

108 Subirá, La tonadilla escénica, vol. II, pág. 386.

${ }^{109}$ En el apogeo del género, los personajes solían pertenecer a las clases sociales más humildes, hombres y mujeres que vivían de oficios manuales que contrastaban con los de los «usías, petimetres, letrados, alcaldes y otras personas de autoridad y prestigio social, a las que se los solía enfrentar intencionalmente» (albañiles, carpinteros, cesteros, hojalateros...); gentes que atendían pequeños negocios (fondistas, venteros, posaderos...); vendedores y vendedoras ambulantes (rabaneras, avellaneras, besugueras...); y las más diversas profesiones: arrieros, toreros, peluqueros, barberos, cocheros, lacayos, adivinos, contrabandistas, bandoleros, peregrinos... Por lo que respecta a los asuntos, las tonadillas destinadas a un solo personaje solían ser satíricas, picarescas, narrativas o alegóricas, y las escritas para varios interlocutores trataban casi siempre de costumbres y tradiciones populares, vid. Subirá, La tonadilla escénica, vol. II, págs. 87 y sigs. 
yen un inagotable caudal de recursos folklóricos. En todos es lugar común la «mirada humorística» de lo popular, la chanza, la broma, la burla de lo diverso, de lo curioso, de lo distinto.

Frente a la «pintura objetiva de las costumbres observadas», estas otras «visiones de las Españas» se caracterizan por el desfile de tipos populares por paisajes que no son los suyos — la Corte generalmente-; personajes que responden al estereotipo regional que la mentalidad colectiva ha ido formando y cuyo fin no es otro que hacer reír. Estos «rústicos» suelen ir acompañados de una parafernalia identitaria — hablas, trajes, bailes, canciones, instrumentos...que no deja lugar a dudas sobre la procedencia de cada uno y, al mismo tiempo, contribuye a provocar aún más risa. «Ello no obedecía, claro está, a una búsqueda de color local o planteamientos literarios de signo regionalista como los que se darán años después. Se busca ante todo una ridiculización que asegure la comicidad de la obra ${ }^{110}$ ».

«Los sainetes de Ramón de la Cruz no son una mera colección de las costumbres populares, sino una rica enciclopedia popular puesta en acción en vez de artículos», escribe con vehemencia Joaquín $\mathrm{M}^{\mathrm{a}}$ de Navascués a propósito de este otro folklorista del xVIII: «¿No es la suya una obra de recolección demosófica, que diría el señor Guichot y Sierra? ${ }^{111}$ ». Son incontables los sainetes de don Ramón (1731-1794) que tocan el tema de la música, sea el de las academias, sea el de la melo-italo-manía de los nuevos tiempos. Cualquiera es bueno para sacarlo a escena: el de las serenatas o músicas nocturnas, el de los músicos hambrientos, el de los bailes de candil y velón. Por sus obras desfilan docenas de instrumentos y cantares que aguardan un estudio que aquí sólo cabe apuntar. La Crítica, la Señora, la Primorosa, la Linda; Los picos de oro; El fandango de candil; El casamiento desigual; Introducción a la Tragedia ridícula de Manolo; Manolo; La merienda a escote; Las castañeras picadas; La Petra, la Juana o El casero prudente, son títulos que además de estar plagados de referencias musicales del más diversos signo, también son un retrato «de las incidencias, de las ocurrencias, de los comentarios a que daban y dan lugar tales espectáculos entre quienes los presencian, [...] porque en el baile o danza, como en cualquier otra diversión pública, hay dos cosas que observar y estudiar: la una la diversión en sí; la otra, los espectadores ${ }^{112}$ », tercia Navascués en defensa del método de don Ramón y, sin pretenderlo, del de la más moderna etnomusicología.

\footnotetext{
${ }^{110}$ Urzainqui, «Visiones de Las Españas», pág. 402.

111 Navascués, «El folklore español», pág. 103.

112 Ibídem, pág. 105.
} 
Las provincias españolas unidas por el placer ${ }^{113}$ (1789) es un desfile de tipos y caracteres regionales a los que la música contribuye a diferenciar, «lo que debió jugar un papel importantísimo en la brillantez del espectáculo y en el lucimiento de los actores ${ }^{114}$ ». Los bailes e instrumentos que se mencionan son los siguientes: de cuenta, boleras, carricadanzas, danza prima ${ }^{115}$, muñeira, palitroqueo o palitroqueado, seguidillas, seguidillas boleras y seguidillas manchegas (también denominadas «al aire manchego» o simplemente «bailar a lo manchego»), por lo que respecta a los primeros; y bandurrias, cascabeles, dulzainas, flautas, flautillas, gaitas (gallega y zamorana), guitarras, panderos, sonajas de yerro, tambores, tamboriles y tiples, por lo que respecta a los segundos. Abundan en la obra expresiones musicales de la más diversa índole, como «cantar versos», jácaras, cantinelas..., y hasta contiene la transcripción literal del texto de una tirana:

(Bailan el palitroqueado; y después, salen cantando una tirana graciosa, con las guitarras, las señoras, y hombres que quieran, de andaluces, dos de choriceros. Salen con una copla que concluyen, y luego callan.)

En la villa de Madrid

dicen que hay mucho que ver,

y que es nada comparado

con el mérito del Rey.

Ay, tirana tirana,

ay tirana nueva,

ven de Andalucía

a ver a la Reina;

¡verás qué agasajo,

verás qué presencia!

Ay tira tirana,

tirana no seas;

ven de Andalucía

a ver a la Reina.

(Cruz, Sainetes, pág. 457, vv. 428-441).

\footnotetext{
${ }^{113}$ Con el siguiente subtítulo: Fin de fiesta, con que Madrid celebró la entrada del señor don Carlos IV en la corte con su esposa, la señora doña Luisa de Borbón y la jura del príncipe don Fernando. Vid. Cruz, Sainetes, págs. 433-464.

114 Urzainqui, «Visiones de Las Españas», pág. 410.

115 Vid. n. 49.
} 
El material que nos proporcionan poetas y prosistas españoles -filósofos, pensadores, costumbristas, satíricos, músicos teóricos, médicos- es tan abundante que un estudio detallado del mismo, imposible de realizar aquí, sacaría a la luz muchas más referencias musicales de esta índole.

\section{Diego de Torres Villarroel}

Quisiera terminar con uno de ellos, que abre más que cierra el tema que nos ocupa, que es de lo que se trata. El catedrático salmantino Diego de Torres Villarroel (1694-1770) es un «singular caso de barroquismo». Autor de una polifacética producción en la que rezuman variadas referencias de orden musical, «es Diego de Torres la otra cara de la moneda de la Crítica: Feijoo grave, serio, solemne; Torres, burlón desenfadado, se ríe de todo y de todos, empezando por sí mismo ${ }^{116}{ }_{»}$. Feijoo deseaba una España a la altura de los países más desarrollados de Europa, y sus escritos dan testimonio de esta preocupación y del conocimiento que desde su atalaya ovetense tenía de los cambios que se estaban produciendo en Europa. «Torres se separa de Feijoo, no sólo por sus ideas y por sus juicios sobre el célebre benedictino, sino también porque sus contemporáneos ven en él y el autor del Teatro crítico dos espíritus completamente opuestos ${ }^{117}$ ». Nos interesa empero, el singular acercamiento del catedrático salmantino a la realidad musical de su tiempo. Al menos, nueve de las treinta «visiones y visitas» de su más célebre obra ${ }^{118}$ tocan el tema que aquí nos ocupa y constituyen una singular etnografía sonora de la villa y Corte, además de un buen ejemplo del «espíritu filarmónico» que animaba al doctor Villarroel ${ }^{119}$.

La visión y visita primera fue a los barberos, y en ella se contrapone el «sonido de las vihuelas» del pasado al «reclamo de los rabeles» del presente:

Por el Caballero de Gracia arriba íbamos los dos; y a poco trecho se nos colgó de las orejas un sonido entre acento de rabel y dejo de rebuzno, y a veces tan rabioso, que pareció maúllo concebido en caniculares de lujuria gatesca.

- ¿Quién toca tan desapacible? — dijo Quevedo [...].

[...] Estaba sentado en el sillón de pelar entrecejos, sirviéndole de cabalgadura uno de los muslos al otro, y serrándole las cuerdas a un violín con tal desconsuelo, que parecía salir el son de entre agallas de burro melancólico.

\footnotetext{
116 Martín Moreno, El Padre Feijoo, pág. 231.

117 Russell P. SEвold, «Introducción», en Diego de Torres Villarroel, Visiones y visitas con don Francisco de Quevedo, Madrid, Espasa-Calpe, 1991, págs. 11-95, pág. 50.

${ }^{118}$ Diego de Torres Villarroel, Visiones y visitas con don Francisco de Quevedo, ed. Russell P. Sebold, Madrid, Espasa-Calpe, 1991. Sobre la obra de Diego de Torres, vid. Emilio Martínez Mata, Los «sueños» de Diego de Torres Villarroel, Salamanca, Servicio de Publicaciones de la Universidad de Salamanca - Instituto Feijoo de Estudios del Siglo XVIII, 1990.

119 Subirá, Historia de la música española, págs. 611-615.
} 
—Ves aquí —le dije a Quevedo—; éste es el que tocaba antes [...].

[...] Los ratos que vacaban los aprendices de barbero, tañían cuatro pasacalles en una vihuela [...]. Entonces acudían las barbas al sonido de las vihuelas, y ahora se convocan a los que no están afelpados de carrillos al reclamo de los rabeles. (Torres Villarroel, Visiones y visitas, págs. 135-137).

En la visita novena — a los pobres del hospicio — un «hombre con raza de mico» resume el triste fin de los bailes de antaño. Habrá que esperar a la segunda mitad del siglo para que los bailes nacionales compitan con los franceses e italianos y los boleros, seguidillas y fandangos acaben ganándole la partida a las contradanzas y los minuetes:

Este chisgarabís — dije a Quevedo- daba lecciones de saltar, era maestro de música de movimientos, director de pavanas y solista de cabriolas. Éste, después que se tomaron de orín los bailes que se usaban en tu edad, caduco de hambre, se arrimó a las muletas del Hospicio [...]. Ahora se usan otras danzas, que son sementeras del cabronismo [...] porque son unos bailes, especialmente en las damas, más afectuosos y más blandos que sus lágrimas y tan espirituosos, que resucitan la más difunta concupiscencia. (Ibídem, págs. 176-177).

El paisaje de «petimetres y lindos» que recorren los ojos de nuestros dos protagonistas en la visita décima, trae a la memoria de don Francisco cierta práctica de su tiempo:

El que mejor dirigía la crianza de su hijo, era buscándole un maestro de danzar para quitarle la torpeza de los miembros y arreglándole a pisar con arte el suelo de un estrado. A tal cual aleccionaban en la música, a otros en saber domar a un bruto. (Ibídem, pág. 185).

La visita undécima, al «corral de comedias, poetas líricos, cómicos y representantes», se despacha de nuevo con la añoranza del pasado:

Ahora no suenan sino es cucos y cigarras, chirreando enfadosamente los oídos de los que escucharon aquellas calandrias y ruiseñores. Toda la armonía de este siglo es sonajas, pitos de capador y zambombas [...]. Las comedias ya no las hacen los poetas, sino es los músicos, hortelanos y carpinteros [...]. Toda la casta de poetas villanciqueros que surtían de coplas de Gil y Menga las Navidades y los que escribían jacarandainas para los ciegos, se han arrimado a los cómicos, y se ahogan los pobres en poetas, oyendo continuamente sus rebuznos. Y si no los 
confundiera la grave y sonora armonía de la música moderna, fuera lo mismo que escuchar los alaridos de la tortura [...]. Y al punto salieron las guitarras; y mi difunto, habiendo oído en pie los primeros números de un área, sin poder sufrir la necedad de la composición poética, marchó, y yo detrás de él, y tan enojado, que no me atreví a preguntarle su parecer en la moderna cultura de coplear. (Ibídem, págs. 194, 196-197 y 200).

«Músicas y estrados», la visión duodécima, es un corrosivo dibujo de la profesión que recuerda — y completa — el de 〈Don Preciso〉, quien había tildado a los músicos de «rutineros», ignorantes, miserables, caprichosos y estúpidos ${ }^{120}$ :

[...] y desmoronando la esquina que sube a la calle de las Carretas, vimos un envoltorio de hombres más alegres que el tamboril de Baco, más locos que un buen año, más ociosos que el que tiene beneficios simples y más retozones que asno que espera lluvia. Unos eran aplastados de gestos; las bocas se desbocaban a los oídos, rosas burlonas, bailándoles tarantelas los ojos y zarabandas los semblantes. Otros, mohínos de fisonomía y zainos de guiñaduras. Uno se reía a empujones, con más falsedad que el alma de Judas. Otro se mofaba de su mismo compañero, pues detrás de los cariños se le bullían las burlas. Estaban todos dando solfas de murmuración a cuantos veían y descompasadamente hiriendo con la lengua, no la opinión, sino las figuras de los que pasaban por la calle, no valiéndoles la confusión del concurso para ocultarse de su fisga descomunal. Todos eran jorobados de ijares, y enseñaban unas muescas por los lomos, más hundidas que alma de condenado; y reparando bien, advertí que aquellas corcovas eran sus pies y sus manos. A uno se le descollaba un trapo verde por los pliegues de la gabardina, y a otro se le reconocía una tarazón de flauta asomado por mala parte.

Dijo Quevedo:

—¿Qué gente?

Yo le respondí:

—Éstos son alanos que se cuelgan de las orejas, que hacen su presa en el oído y viven pendientes de todos. Estos son músicos, el costado más alegre de los cuatro que tiene la locura. Aquí están de venta, esperando a alguno que los llame

${ }^{120}$ El despecho de Iza Zamácola tenía que ver con el desprecio que los músicos sentían por nuestras tradiciones y el abrazo en que se fundían con las modas italianas y francesas (Iza Zamácola y de Ozerín, Colección de las mejores coplas de seguidillas, vol. I, pág. xxv):

$[\ldots]$ porque nuestros músicos, siempre rutineros y eternamente ignorantes, dieron en ensalzar la música de la ópera y despreciar la nuestra en tanto grado que a muy poco tiempo vimos ya mirar como a un anticuario ridículo a todo aquel que se dedicaba a componer seguidillas, tiranas y otras canciones españolas. ¡Miserables! ¿qué no podremos decir de vuestra ignorancia y estupidez, cuando vemos que preferís para cantar en nuestras iglesias ese hediondo surtido de arias italianas? 
para holgar y darles el dinero. Éstos son los que gozan las delicias de la Corte y sus bienes. Hay mujer que vende las mantas por dar dos pesos a uno que la toque el rabel, que éste es el instrumento más palpado. Los hombres ricos de Madrid son los músicos, los médicos, los boticarios y los sastres; pero éstos son los que hacen más ruido en la Corte.

[...] cuando nos arrebató al oído el mormullo de los violines, que parecían petrales de cascabeles y jaulas de grillos.

—Ya empieza el sarao — le dije a mi difunto—; no pierdas la ocasión. Quedémonos arrimados a la puerta, que desde aquí verás la alteración de las diversiones.

Salió una dama cosida al lado de uno de los concurrentes a bailar un minuete [...] (ibídem, págs. 201-202 y 204-205).

«Las comidas y cenas», visita decimatercia — como otras en las que no podemos detenernos para no alargar en exceso la relación-, es una plástica y despiadada crítica a los placeres sin freno de la mesa en la que no faltan alusiones musicales del más diverso tipo:

Antes no hallaban la mano, aun para dársela a su marido; hoy es cosa que está de balde (como lo has visto), pues en cualquiera danza se le hace barato al que la quiere [...]. Aquél prosigue en bailar [...]. Uno canta un responso pasado por rosolí; otro hace relinchar un rabel [...] (ibídem, págs. 208 y 210).

De nuevo sale perdiendo el Madrid de Torres frente al de Quevedo en la visión y visita tercera de la segunda parte del libro, «de los avaros, usureros y mohatreros que prestan dinero sobre alhajas», cuyo interés es doble por el apunte - breve, pero importante- de otra trágica comparación, la opulencia de la Corte frente a la «carencia del resto de la España»:

En cuanto a alegría, jamás hubo tanta en la Corte: aquí no se hace otra cosa que bailar y tañer; cuatro mil músicos más tiene hoy Madrid que los que pagaban en la era que tú eras viviente; ahora al que sabe serrar en un rabel le dan mil ducados de salario; y a los que cantan lo que no se les entiende, dos mil; abundan las calles, las casas y los templos en chirimías, violines, flautas, cuernos, clarines y timbales, instrumentos que ni los habrás oído nombrar [...] a todos les sobra para coche, visitas, gorronas y músicas y otros desórdenes. Toda esta abundancia es hija de la universal carencia del resto de la España [...]. Aquí todo se consume, y allá quedan consumidos; aquí apoplejías y allá hambre, aquí joyas y galas y allá desnudez (ibídem, págs. 243-244). 
Al hablar de «los sastres, zapateros, reposteros y otros mecánicos» en la visión y visita segunda de la tercera parte del libro, Torres alude de nuevo al desahogo económico de los músicos en una Corte que vive a los dictados de la moda, locura que, igualmente, se ha enseñoreado de la fe, recordándonos sus palabras en este punto las del Padre Feijoo. Madrid y su Corte eran el modelo a imitar. Las plazas a cubrir en sus codiciadas capillas musicales y un nuevo público, dan fe de otra que se vive de manera bien distinta, en donde «la música religiosa es un elemento imprescindible en el esplendor espectacular del culto y un medio infalible para atraer a los fieles ${ }^{121}$ ».

Hoy viven, y se han ido chupando el dinero los sastres y los peluqueros franceses, los médicos italianos, los mercaderes alemanes, los zapateros, aguardenteros, relojeros, espejeros, danzarines, músicos y otros acompañamientos [...]. Los remolones y perezosos a la asistencia de los cultos de Dios somos los que vivimos fuera de las religiones; y es necesario, además de la campana, llamarnos con clarines y timbales [...]. Y para que lo acabes de creer, sabe que hasta en los carteles convocatorios a la devoción que ponen por esas esquinas para señalar el día festivo, lo primero que advierten es que Predicará el padre Fulano, y este renglón es de letra bastardilla, y después, de letrones muy hidrópicos, Asistirá la Música de las Señoras Descalzas, o del Rey, con violines, etc. Porque temen que no asista la gente si no les dicen que hay también holgueta entre la devoción; y el templo en donde no suenan músicas festivas, y la iglesia que no tiene sabor a coliseo, está desierta, lo más del año.

—¿Qué dices? ¿Bastidores, timbales y clarines en los templos sagrados? —dijo Quevedo como lloroso.

—Sí —le dije-, yo lo he visto y oído mil veces.

-Bueno será, cuando se hace tan público — replicó, encogiendo los ojos y dolorido de semblante (ibídem, págs. 327-328 y 335-336).

La penúltima visita, a «la librería del Rey y los soldados», es aprovechada por Torres para caricaturizar las «letras vestidas con músicas al uso $^{122}$ » desde el comienzo mismo de la visión: «¿Ves esa fachada que en tu tiempo fue pasadizo al templo de las señoras de la Encarnación y casas para los músicos y cantores de su Real Capilla? Pues hoy es la más suntuosa biblioteca de las cortes». «Sastres de villancicos» y «químicos cómicos» son pasados por la piedra de Torres sin más contemplación:

\footnotetext{
${ }^{121}$ Antonio Martín Moreno, Historia de la música española, 4. Siglo XVIII, Madrid, Alianza Editorial, 1985, pág. 90.

${ }^{122}$ SuBIRÁ, Historia de la música española, pág. 613.
} 
Éste es poeta cómico entremesero con sus tiznones de químico. Parió su musa en las frondosidades de Aranjuez un auto sacramental tan redomado como su persona, en que entraban las once mil vírgenes, y en él tenía tres villancicos a San Bernardo, San Francisco y las ánimas del purgatorio. Acuérdome que el de San Francisco decía:

Contar quiero las llagas

de mi padre San Francisco,

una, dos, tres, cuatro, cinco.

Estribillo. Alegrémonos, alegrémonos, porque es bien que nos alegremos.

El de San Bernardo era otro a solo, que decía de esta suerte:

San Bernardo no come escabeche

ni campeche,

porque es amigo de leche.

Estribillo. Y al glorioso mamón

digámosle todos

Kirie, Kirieleisón.

El villancico a las ánimas era un dúo en esta forma:

¡Ay, que se quema;

ay, que se abrasa

el ánima que está en pena!

El otro coro.Pues abrásese enhorabuena,

que yo estoy en mi casa.

Todos.¡Ay, que se quema;

ay, que se abrasa, etc. (ibídem, págs. 348-349).

Tras la edición príncipe de las Visiones (1727-1728), la segunda (1743), que se titulaba Sueños morales. Corregidos, y aumentados con el papel nuevo de la Barca de Aqueronte, y residencia infernal de Plutón, incluía dentro de éste un «Juizio sexto y vltimo de varios Precitos de todas species, Músicos, Poetas, Danzantes, Pintores ${ }^{123}$ », cuyo encabezamiento renueva por sí solo la mala fe de los artistas condenados al infierno. Ya en el «Sueño» inicial del añadido nos encontramos con esto:

Quedose mi Diablo conmigo el vltimo conmigo, y presentándome [a] un Demonio que tenia cara de Puto, le dixo: "Este Muerto lanza fue vn Perdulario y bribon

${ }^{123} \mathrm{El}^{\circ}$ en la ed. de Guy Mercadier (1969) que es la que utilizo: Diego de Torres Villarroel, La Barca de Aqueronte (1731), éd. critique d'un autographe inédit par Guy Mercadier, Paris, Centre de Recherches Hispaniques, 1969. 
entre las gentes, el Panderillo de las fiestas, la Gaita gallega de los concursos, el fandango de los combites y el cumbe de las Bodas. Su vida la ha repartido entre Danzas, toros, caminos, coplas, chacorrerias (sic), juizios Astrológicos disparatados y otros desconciertos considerables [...]" (Torres Villarroel, La Barca de Aqueronte, pág. 102).

Las citas musicales son muchas y diversas, como esta: «Auia este sido, en sus principios, mequetrefe de la Poesia y de la Musica. Despues de fabricar coplas de Peñasco y de cantar como un Mastin» ("Juicio $1^{\circ}$ de los Medicos», págs. 117-118). De los músicos leemos lo siguiente:

Los otros fueron cigarras de los estrados, campanillorros de las visitas, Pitos de castrador, tamboriles de titiritero, obues de campiña, sonajas de foligon, gaitas Zamoranas y gallegas de todo concurso. Viuieron estos camaleones, Paxaros de Pico redondo, rebuznando estriuillos, gimiendo arias, llorando recitados y vomitando $x$ acaras, coplillas y juguetes (sic), estercolando el aire, los oidos y las almas con amorosas ternezas, lasciuas expresiones y reclamadores ademanes, para despertar con el hermoso ruido de las solfas los pensamientos acostados, las memorias difuntas, las ausencias oluidadas, los sosiegos ociosos, las luxurias dormidas y otros afectos que inquietan a los spiritus mas castigados y religiosos (ibídem, págs. 342$344)$.

y de los danzantes esto otro:

Componia $<$ se la $>$ inmund $<a>$ majada $<$ de $>$ otra rumfla de compositores de Almagro, Zarambeques, Santigallos, langostas, chotos, cabras, Peonzas, cascaueles y otros monicongos y saltarines de la racionalidad. Estos auian roto la vida, los vestidos y los zapatos en desordenados mouimientos. Con los cascos al trote y los pies en tarabilla y baraunda, enseñaban libertades, desuellos y descomposturas à los cuerpos, y con la solfa de sus fandangos, el compas de sus minuetes y la desproporcion de sus meneos, maltrataban la grauedad y compostura natural, sacaban de su retiro la modestia, impacientaban la lasciuia, y, ultimamente, fueron el reclamo de las liuiandades, locuras y desbaratos, y el esquilon para juntar ociosos, regalonas, perdularios y saltimbanquis (ibídem, págs. 344-346).

y de todos:

Acabò esta abrigada que componia el pestilente batallon de la locura de Musicos, Poetas y danzantes llenos de las costras de sus culpas, los manchones de 
sus delitos, tiznados de el color de sus tablas, vnguentos y paletas, y descoloridos de las importantes tinturas de el arrepentimiento y Penitencia (ibídem, pág. $350)$.

Más textos de este «centauro mixto», como llamó Sebold a Torres ${ }^{124}$, redundarían en esta pintura singular de lo cotidiano: de «felices villanciqueros», «festeros y congregantes», «atarantados» $y$ «poetas de obra gruesa ${ }^{125}$ », tan importante y tan difícil. No es preciso.

En los Sueños de Torres salen a relucir sonadores del más diverso tipo y uso: campanas, «campanillorros», cascabeles, clarines, cuernos, chirimías, esquilones, flautas, «gaitas zamoranas y gallegas de todo concurso», guitarras, «matracas de lazarillo», «obues de campiña», «panderillo de las fiestas», pitos de capador, rabeles, «sonajas de foligon ${ }^{126}$ », tamboriles y «tamboriles de titiritero», timbales, vihuelas, violines, zambombas... El instrumento más nombrado — y el «más palpado» al decir del propio Torres— es el rabel, que el escritor contrapone a la vihuela y al que recurre en casi todas las hipérboles que utiliza para caricaturizar a los músicos de su tiempo. Los demás se distribuyen a partes iguales entre «la armonía de este siglo» (sonajas, pitos de capador, zambombas...) y los que pueblan «las calles, las casas y los templos» (chirimías, violines, flautas, cuernos, clarines, timbales...: «instrumentos que ni los habrás oído nombrar»).

Pasacalles, «áreas», «recitados», «coplillas», «juguetes», jácaras y «jacarandainas para los ciegos» son algunos de los repertorios —instrumentales y literario-musicales - que hemos encontrado en los Sueños de Torres, que se completan con los cumbés, fandangos, minuetes, pavanas, tarantelas, zarabandas y zarambeques ${ }^{127}$, por lo que a danzas se refiere. Pero no es la nomenclatura o relación de instrumentos, bailes y canciones lo que más interesa de la obra del catedrático salmantino, sino el contexto en que aparecen y el comentario que Diego de Torres realiza al respecto, es decir, lo que, exagerando las cosas, hemos dado en calificar de «etnografías sonoras» de la Corte. Aquí sí que es rica y abundante la relación.

\footnotetext{
${ }^{124}$ Sebold, «Introducción», en Torres Villarroel, Visiones y visitas, pág. 11.

125 Gallego, La música en tiempos de Carlos III, págs. 153-176.

126 «El tañido llamado folías, tocado sin orden ni concierto» / «cierta danza portuguesa en que entran varias figuras con sonajas y otros instrumentos que tocan con tanto ruido y el son tan apresurado que parece están fuera de juicio» (Dic. de Autoridades, 1726-1739). N. 312 de la ed. de Guy Mercadier, vid. Torres Villarroel, La Barca de Aqueronte, pág. 429.

127 «Tañido y danza muy alegre y bulliciosa, la cual es muy frecuente entre los negros» (Dic. de Autoridades, 1726-1739). N. 316 de la ed. de Guy Mercadier, vid. Torres Villarroel, La Barca de Aqueronte, pág. 429.
} 
Intentando resumir esos paisajes, diría que son varias las caricaturas musicales que pinta Torres, siendo la más importante a mi juicio la de los propios músicos, que aquél lleva a efecto en la visión duodécima de la primera parte, «músicas y estrados», y que completan otras visitas del libro. Torres dice, en primer lugar, que en la Corte los músicos son muchos y colman hasta las iglesias ${ }^{128}$ : «cuatro mil más tiene hoy Madrid que los que pagaban en la era que tú eras viviente [...]», «y el templo en donde no suenan músicas festivas [...]». En segundo lugar los músicos son para Torres «los que gozan las delicias de la Corte y sus bienes», los «hombres ricos» de la Capital (junto con los médicos, los boticarios y los sastres): «ahora al que sabe serrar en un rabel le dan mil ducados de salario; y a los que cantan lo que no se les entiende, dos mil [...]», «hoy viven, y se han ido chupando el dinero los sastres y los peluqueros franceses, los médicos italianos, los mercaderes alemanes, los zapateros, aguardenteros, relojeros, espejeros, danzarines, músicos y otros acompañamientos [...]». Tal dispendio es fruto de la «universal carencia del resto de la España» concluye Torres (recordándonos a Jovellanos):

A cualquiera pueblo que vieras conocerías al punto su miseria. En ellos sudan y trabajan para mantener a los ociosos cortesanos y a los que llaman políticos. Al rabo de una reja anda cosido todo el día el desventurado labrador, y el premio de sus congojas es cenar unas migas de sebo por la noche y vestir un sayal monstruoso que más lo martiriza que lo cubre, y el día de mayor holgura come un tarazón de chivo escaldado en agua. Los caudales de las villas aldeas y ciudades, todos vienen en recuas a la Corte. Aquí todo se consume, y allá quedan consumidos; aquí apoplejías y allá hambre, aquí joyas y galas y allá desnudez (Torres VILLARROEL, Visiones y visitas, pág. 244).

«El costado más alegre de los cuatro que tiene la locura» dice nuestro autor de los músicos, a quienes tilda de ociosos, retozones, burlones, murmuradores y porfiados, «los más ruidosos de la Corte», donde «no se hace otra cosa que bailar y tañer». La frase resume bastante bien el pensamiento de Torres Villarroel sobre la música de su tiempo. Si antaño «el que mejor dirigía la crianza de su hijo, era buscándole un maestro de danzar para quitarle la torpeza de los miembros», hoy los bailes no son otra cosa que «sementeras del cabronismo», resurrección de la concupiscencia más difunta: «toda la armonía de este siglo es sonajas, pitos de capador y zambombas [...]». La hipérbole de Torres llega

${ }^{128}$ Con alguno Torres debió cierto trato, hecho que se deduce de la Respuesta de D. Diego de Torres a una carta de don Joseph Herrando, músico violinista de la Capilla Real, a que hace referencia el profesor Martín Moreno, Historia de la música española, págs. 262-263. 
al paroxismo cuando retrata los sonidos de la ciudad: «maúllo concebido en caniculares de lujuria gatesca». La metáfora ha dejado de serlo para convertirse en el látigo con el que nuestro autor ultraja a diestro y siniestro: las cuerdas de los violines se sierran con desconsuelo..., los responsos se pasan por rosolí, otros hacen relinchar un rabel..., y su son es lo más parecido a los alaridos de la tortura... Y qué decir de las comedias, que ya no las hacen los poetas, sino los músicos, hortelanos y carpinteros...

Hace más de diez años que Russell P. Sebold puso de manifiesto los muchos lazos que unen la inquietante pintura ascética de El Bosco con el expresionismo literario de que hacen gala las Visiones de Torres. La música y los músicos de su tiempo, el baile y la danza, los instrumentos, dan al ingenio de este escritor sobrados recursos para «horrorizar con su imagen» los vicios que va a presentar, en donde pecador y pecado son una y la misma cosa: «Todos eran jorobados de ijares, y enseñaban unas muescas por los lomos, más hundidas que alma de condenado; y reparando bien, advertí que aquellas corcovas eran sus pies y sus manos»: así es como Torres pinta a los músicos. A golpe de analogías, sus físicos han abandonado el sueño para convertirse en hombres y mujeres de carne y hueso, por ello, si cabe, su pecado es aún más ruin. Un pecado que Torres, como El Boso, combate con una pluma que es casi como un pincel... El pincel de la locura ${ }^{129}$.

Los repertorios de estos singulares personajes, como casi todos los que han acompañado el discurrir de la vida del hombre desde la cuna hasta la sepultura, se han perdido para siempre. Pasaron desapercibidos, cuando no despreciados, para casi todos. Y si no fuera por «visiones» como las que hemos desgranado en estas páginas - pequeño ejemplo de lo que una búsqueda más sosegada pudiera dar de sí- se habrían perdido para siempre.

${ }^{129}$ En la literatura, como en la tradición oral, músicos y locos caminan de la mano, no en vano Melchor de Santa Cruz metió en el mismo saco de la Sexta parte de su Floresta española de apotegmas (1574), los dichos y cuentecillos «de amores, de músicos, de locos...», vid. Melchor de Santa Cruz Dueñas, Floresta española de apotegmas, o sentencias, sabia y graciosamente dichas, de algunos españoles. Rec. por... vecino de la ciudad de Toledo, Madrid, Ediciones Atlas, 1943, págs. 109-133. 